\title{
ODRAZ PROCESU CHRISTIANIZACE NA VYBRANÝCH POHŘEBIŠTÍCH PŘEMYSLOVSKÉ DOMÉNY
}

\author{
DRAHOMÍRA FROLÍKOVÁ-KALISZOVÁ
}

\begin{abstract}
Abstrakt: Centrálni oblast přemyslovské domény byla v poslední čtvrtině 9. a první polovině 10. století ohniskem, z něhož se křest'anství šiŕilo do celých Čech. Se záměrem hledat odpověd' na otázku, jak se postup christianizace projevil, bylo v této oblasti vybráno devět kvalitně publikovaných pohrebišt', která poskytla průřez společenskými vrstvami od členů knižeci družiny přes obyvatele hradišt’ i podhradi až po venkovany. Srovnání jevů, v archeologické literatuře tradičně vykládaných jako projevy krest'anství-ubývání milodarů, vzrůstajici podil dětských pohřbů, použití kamene při úpravě hrobů-ukázalo, že se na jednotlivých pohřebištich liší, avšak spíše jen v detailech, jejich chronologickým rámcem zůstává 10. století. Patři k nim i přechod od skupinového k řadovému pohřbívání, který je ale pozorovatelný pouze na pohřebištích ve volném terénu. Tzv. protivampyrické zásahy, dřive považované za projev předkřest’anských tradic, se jevi být většinou důsledkem nekritického posouzení posunů nebo chybění částí kostry u staršich výzkumů.
\end{abstract}

Klíčová slova: christianizace - pohřebiště - středni Čechy - 10. století.

\section{The reflection of the Christianization process in selected burial grounds of the Přemyslid domain}

Abstract: The central area of the Prremyslid domain was the focal point from which Christianity spread throughout Bohemia in the last quarter of the 9th and the first half of the 10th century. With the intention of seeking an answer to the question of how the process of Christianization manifested itself, nine well-published burial sites were selected in this area, which provided a cross-section of social strata, from the members of the princely retinue through the inhabitants of hillforts and the settlements below them to the rural population. A comparison of phenomena traditionally interpreted in the archaeological literature as expressions of Christianity - the decline of almsgiving, the increasing proportion of child burials, the use of stone in grave preparation - showed that they differed from site to site but only in details, with the 10th century remaining their chronological framework. This includes the transition from group to row burials; however, it can only be observed with open-landscape burial grounds. So-called anti-vampire interventions, previously considered manifestations of pre-Christian traditions, appear to be mostly the result of uncritical assessment of displacements or missing skeletal parts with earlier excavations.

Key words: Christianization - burial ground-central Bohemia-10th century.

Na úvod je třeba položit si otázku: Od čeho vlastně měli tehdejší lidé přecházet ke křest’anství, co to bylo to jejich slovanské ,pohanstvi““? Dá se říci, že to vůbec nebylo náboženství v dnešním slova smyslu, ${ }^{1}$ nýbrž že šlo spíše o souhrn pravidel a obyčejů (,starobylý zákon, zákon našich otcư'“), podle nichž lidé žili. Jejich svět nerozlišoval sacrum a profanum (Dynda 2017, 14-15), nebot' archaická víra vykládala celý svět (vesb mirb) a určovala zcela profánní vzájemné vztahy v lidské komunitě - právo/pravbda (Téra 2014, 40). Z historiků došel k obdobnému výsledku D. Třeštík - spořádaná slovanská společnost se nazývala mir/mír, kteréžto slovo v sobě obsahovalo lidi žijící v míru na vlastním území (Třeštík 2003, 98). O konkrétních představách a jejich ztělesnění v podobě božstev toho mnoho nevíme, pro oblasti Čech, Moravy, Slovenska a jejich slovanského okolí máme jen písemné prameny mladší, ovlivněné tím, že je psali kněží znalí antické mytologie, kteří navíc byli většinou neslovanského původu (Dynda 2017, 10-13).

Christianizace tedy znamenala nahrazení dosavadního způsobu nejen chování, ale dokonce i myšlení, chápání okolního světa. To pochopitelně nešlo aktem křtu s krátkým „poučením“ před tím, nýbrž musel to být proces postupné změny, výchovy od dětství, což znamená nejméně dvě, spíše však tři generace, po kteroužto dobu se projevoval stav dnes nazývaný dvojvěří

1 V prostoru euroamerické civilizace je dnes náboženství pojímáno jako záležitost povýtce osobní, víra a s jejím praktikováním spjaté církevní instituce jsou oddělené od zákonů přijímaných a vyžadovaných světskými institucemi. 
(Sommer 1996, 141; Zoll-Adamikowa 1997, 77, uvádí dokonce 150-200 let; Slivka 2000-2001, 27; Chorvátová $2004 \mathrm{~s}$ přehledem dosavadní literatury).

Jen stručně se dotknu složité otázky, a to nakolik je projevem přechodu ke křest’anství samotné kostrové pohřbívání. Už L. Niederle konstatoval, že spalování se na širokém území Slovanstva měnilo v pochovávání pod cizím vlivem, aniž se změnilo náboženství (Niederle 1953, 217). J. Eisner psal: „Neznáme a sotva kdy poznáme všechny přičiny, proč predkové nynějšich Čechů a Slováků začali už v době pohanské upouštěti od pưvodniho slovanského zvyku spalování a začali nespálená těla svých mrtvých pohřbivati v mohylách“ (1952, 219). B. Dostál použil formulaci „změna ritu byla spojena s hlubokými prevraty ve světonázorových představách tehdejšich lidi; o príčinách těchto změn se diskutuje“ $(1966,12)$. V rámci celého západního i východního Slovanstva připisuje H. Zoll-Adamikowa (1997) rozhodující roli v přechodu od pohřbívání nespálených těl pod mohylami k plochým pohřebištím christianizaci církví latinskou, zatímco $\mathrm{v}$ oblastech christianizovaných pravoslavnou církví ještě dlouho přetrvávalo pohřbívání pod mohylami. Nově se tématu věnoval I. Štefan a dospěl k závěru, že změna ritu u většiny západních Slovanů proběhla postupně v několika krocích: vládnoucí vrstva po přijetí křest'anství přešla k inhumaci, jež se následně šiřila spíše jako móda do širokých vrstev obyvatelstva, k němuž se křest’anství dostávalo až později. Otázku přechodu od pohřbívání pod mohylami k plochým pohřebištím ponechává bez odpovědi (Štefan 2007). Vzhledem k dřívějšímu nástupu plochých hřbitovů v centrálních oblastech řišíi ${ }^{2}$ Mojmírovců, Přemyslovců i Piastovců a delšímu přetrvávání mohylníků v oblastech od center vzdálených se jeví jako pravděpodobná souvislost ubývání pohřbů pod mohylami s postupem christianizace.

Jak už bylo řečeno, u slovanských národů christianizace začínala shora, křtem knížete a jeho družiny, což často naráželo na odpor (Sommer 1996; Boroń 2004; Žemlička 2014). Archeologové se zaměřovali vedle vzácných objektů interpretovatelných jako pohanská kultovní místa (Krumphanzlová 1971, 414-415; 1997; Marešová 1983, 6-7; Klanica 1985, 485-488; Dostál 1992; Turčan 2004; 2012) na otázky projevů tzv. dvojvěří v podobě synkretických jevů (Krumphanzlová 1990; Hanuliak 2000-2001; Slivka 2004), a v neposlední řadě se zabývali vývojem pohřebního ritu. Šlo jednak o vývoj od mohyl k plochým hřbitovům, jednak o vývoj od pohřbu zemřelého s výbavou pro posmrtný život včetně potravy po prosté uložení zemřelého bez výbavy. Zvláštní pozornost byla věnována projevům tzv. vampyrismu, který byl považován za reziduum pohanství (Krumphanzlová 1961; Marešová 1970; Klanica 1985a).

Na analogie při přechodu od staré víry ke křest’anství u Germánů i Slovanů poukázal P. Sommer - jevy známé z franské říše se objevují, ovšem s časovým posunem, i u západních Slovanů (1996, 138-142). Totéž se týká hrobové výbavy: u nově christianizovaných etnik je bohatá výbava znakem vysokého společenského statusu, ubývá jí postupně během staletí - př́íklady z polských, ruských, langobardských i anglosaských pohřebišt' uvádí A. Buko (2016, 44-47). $\mathrm{K}$ všeobecně uznávaným projevům christianizace patří růst počtu hrobů nejmenších dětí na hřbitovech, který se v Evropě obecně považuje za projev sílícího vlivu křest’anství (např. Unger 2007, 214-215).

Pro Čechy se tématem plochých kostrových pohřebišt' podrobně zabývala Z. Krumphanzlová. Ke konkrétním projevům křest’anství počítá západovýchodní orientaci mrtvých, použití kamene při úpravě hrobu, jehož frekvence výskytu stoupá od konce 9. do 11. století, ubývání hrobové výbavy a změny vnitřního uspořádání hřbitovů (Krumphanzlová 1971, 420-423). Paradoxní je její vysvětlení „křest’anskosti“ orientace, totiž že je mrtvý uložen tváří k vycházejícímu slunci. Přitom již L. Niederle poukázal na předkřest’anský původ tohoto zvyku, když uváděl př́iklad, kdy se pohanští Rusové divili, proč křest’ansky pochovaný kníže Michal není pohřben na znak tváří k východu $(1911,363)$. I. Štefan poukázal na př́pad christianizace Sasů a Frísů, u nichž první kostrové hroby měly orientaci severojižní, teprve později zobecněla orientace západovýchodní $(2007,821)$. Prakticky na každém kostrovém pohřebišti u nás se vedle převažující orientace zhruba

2 Neutrální pojem říše volím namísto termínu stát, jenž je diskutabilní pro období počátků všech zmíněných společenských útvarů. 
západ-východ vyskytne několik hrobů s opačnou orientací, méně často i s orientací sever-jih. Orientace západ-východ bývá vykládána také jako poloha mrtvého tváří k vycházejícímu slunci, pro výrazné odchylky jsou hledána různá vysvětlení, všechna však zůstávají jen domněnkami (konkrétní případy týkající se pojednávaných pohřebišt' viz dále).

\section{Vybraná pohřebiště a kritéria jejich hodnocení}

Chceme-li zkoumat, zda je možné sledovat na plochých kostrových pohřebištích odklon od pohanského ritu a projevy křestanství, musíme postupovat od centra, ze kterého christianizace vycházela. Tím bylo nepochybně sídlo přemyslovských knížat a místo vzniku prvních legendárně doložených kostelů - Pražský hrad a Levý Hradec. Z obou hradišt' jsou však známy jen útržky pohřebišt', navíc většinou s porušenými hroby různé úrovně dokumentace (Frolík 2015; 2017; Frolík a kolektiv 2016; Tomková 2012). Musíme se proto spokojit s jejich nejbližším okolím, odkud naopak máme části pohřebišt’ prozkoumaných v posledních desetiletích, dobře dokumentovaných a kvalitně publikovaných včetně vyhodnocení, ${ }^{3}$ totiž pohřebiště v Lumbeho zahradě Pražského hradu (Frolík-Smetánka 2014; Frolík 2014) a v Jízdárně Pražského hradu (Tomková 2005b) a pohřebiště v areálu Žalova (Tomková 2012; 2020, 33-38). Z pohřebišt' v blízkém zázemí Pražského hradu je ke srovnávání použito pohřebiště Triangl na katastru Střešovic (Frolíková-Kaliszová 2014), k Levému Hradci obě pohřebiště z Klecan na protějším břehu Vltavy (Profantová 2011; Profantová-Krutina 2011). Poslední dvě srovnávaná pohřebiště jsou Motol, vzdálený zhruba 5 km od Pražského hradu (Kováŕík 1991), a Brandýsek (Kytlicová 1968; pohřebiště je však již na katastru Třebusic), vzdálený necelých $7 \mathrm{~km}$ od třetího z ústředních přemyslovských hradišt', tedy Budče (obr. 1), která je zároveň místem stavby kostela iniciované knížetem Spytihněvem, tj. druhou křest’anskou generací Přemyslovců. Obě prezentují typ venkovských pohřebišt'.

Vybraná pohřebiště jsou vesměs plochá kostrová pohřebiště, s převažující západovýchodní orientací mrtvých, uložených obvykle ve zhruba obdélných jámách v natažené poloze na znaku s rukama zpravidla podél těla. Každé pohřebiště je nejprve charakterizováno okolnostmi výzkumu a datováním, následuje jeho rozbor. Budeme srovnávat nejprve poměr pohřbených dospělých a dětí a poměr hrobů $\mathrm{s}$ výbavou a bez výbavy (sumarizované hodnoty $\mathrm{v}$ tab. 1), posléze přistoupíme k podrobnějšímu rozboru jednotlivých pohřebišt' s ohledem na jejich vnitřní chronologii a následuje rozbor kritérií sumarizovaných v tab. 2.

\section{Metodické poznámky}

Vzhledem k charakteru pohřbů jako archeologického pramene je třeba se vyrovnat s různým stupněm zachovalosti kostry, výbavy, hrobové jámy a pochopitelně i torzovitosti pohřebiště. $\mathrm{Z}$ tohoto hlediska je veškerá statistika $\mathrm{v}$ archeologii přesným počítáním $\mathrm{s}$ nepřesnými čísly; nic jiného však k dispozici nemáme. První potíží je počítání jedinců - nebrala jsem v potaz druhotně uložené kosti, prŕměs kostí rozlišenou až při antropologickém posuzování, nálezy kostí několika jedinců v hrobě recentně zničeném apod. Byl-li hrob porušen tak, že nevíme, zda se ve zničené části nacházela výbava, nebo nebylo možno určit, zda jde o dospělého či dítě, pohřeb rovněž není započítán. Mezi děti počítám jedince klasifikované jako infans I-III a infans-juvenis, pokud je věk upřesněn $v$ rocích, pak do 14-15 let. Dospívající jedince 15-18/20 let řadím $\mathrm{k}$ dospělým, nebot' tak tomu v minulosti bylo - např́klad panovníci se mohli ve věku 14 let ujmout vlády (za všechny uvedu jen Jana Lucemburského, Šusta 2002, 96), nemluvě o věku nevěst. Ještě v 19. století odcházeli 14letí chlapci a dívky do služby (nehledě na poměry panující dodnes v mnoha neevropských kulturách).

3 Proto nejsou zařazena pohřebiště na hradišti Budeč, jež postrádají komplexní revizi, nebo pohřebiště v Lahovicích, z něhož je nově publikován katalog bez souhrnného vyhodnocení (Krumphanzlová a kol. 2013), ani pohřebiště Žalov - cihelna A (Tomková a kolektiv 2012; 2020), nebot' z něj neznáme nálezové celky. 


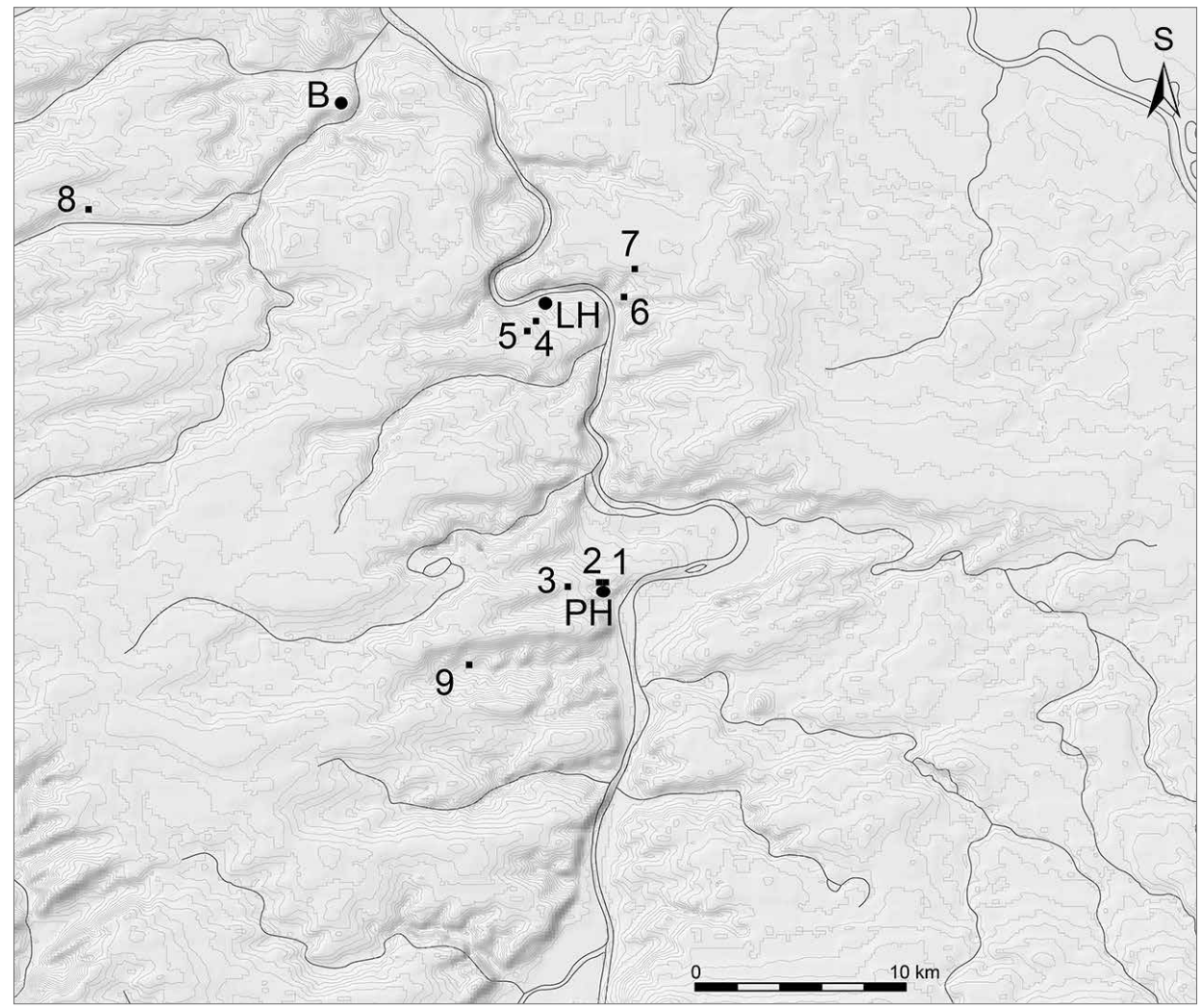

Obr. 1. Přemyslovská ústřední hradiště a vybraná pohřebiště: 1 - Praha - Lumbeho zahrada; 2 - Praha - Jízdárna; 3 Praha - Triangl; 4 - Žalov - Na Panenské; 5 - Žalov - cihelna B; 6 - Klecany II; 7 - Klecany I; 8 - Brandýsek/Třebusice; 9 - Praha-Motol. PH - Pražský hrad; LH - Levý Hradec; B - Budeč.

Abb. 1. Přemyslidische zentrale Burgstätten und ausgewählte Gräberfelder: 1 - Prag - Lumbe-Garten; 2 - Prag - Jízdárna; 3 - Prag - Triangel; 4 - Žalov - Na Panenské; 5 - Žalov - Ziegelei B; 6 - Klecany II; 7 - Klecany I; 8 - Brandýsek/Třebusice; 9 - Prag-Motol. PH - Prager Burg; LH - Levý Hradec; B - Budeč.

Nezabývám se ani odlišnou orientací hrobové jámy nebo kostry, protože tyto se jednak pravidelně objevují na všech pohřebištích, jednak je nelze spojovat výhradně s rituálními př́íčinami, o jejich důvodu se zatím jen spekuluje (literaturu nedávno shrnula Tomková 2020, 69-71).

Výbava se obvykle rozlišuje na věci, které byly součástí oděvu, šperky, jakož i věci běžně nošené na opasku (nůž, křesací souprava), a milodary (Krumphanzlová 1972, 197). Milodar $\mathrm{v}$ pravém slova smyslu (dále jen milodar) představovala potrava reálná nebo symbolická (maso, resp. zvířecí kosti, vejce) včetně jejího obalu (keramické hrnce, mísy, lahve, dřevěná vědérka). Opuštění zvyku vkládat milodary je zásadním přelomem v myšlení, vlastně projevem jeho christianizace; proto nesouhlasím s H. Chorvátovou, že dělení na milodary a „nie milodary“ nemá smysl (Chorvátová 2004a). Dalšími sledovanými jevy jsou použití kamene při úpravě hrobu a posmrtné záměrné zásahy na kostře mrtvého, tzv. protivampyrická opatření (Krumphanzlová 1961, 1964).

Zvláštní kategorií jsou předměty objevující se v hrobech ojediněle, což jsou zbraně, které symbolizují spíše status zemřelého a jeho rodiny (u miniatur zbraní v dětských hrobech), a jiné předměty, význam jejichž prŕtomnosti v hrobě je nejasný. Pro jejich výjimečnost považuji za nutné obě kategorie zařadit do tab. 2. 
Tab. 1. Vybraná pohřebiště z jádra přemyslovské domény s podíly pohřbených dospělých a dětí, s výbavou a bez výbavy (milodary i osobní předměty).

Tab. 1. Ausgewählte Gräberfelder aus dem Kerngebiet des Přemyslidendominiums mit jeweiligem Anteil an bestatteten Erwachsenen und Kindern, mit und ohne Grabbeigaben (Liebesgaben und persönliche Gegenstände).

\begin{tabular}{|l|c|c|c|c|c|c|c|c|c|c|c|c|c|}
\hline pohřebiště & jedinců & dosp. & $\%$ & s výb. & $\%$ & bez v. & $\%$ & děti & $\%$ & s výb. & $\%$ & bez v. & $\%$ \\
\hline Praha - Lumbeho z. & 149 & 84 & 56,4 & 56 & 66,7 & 28 & 33,3 & 65 & 43,6 & 33 & 50,8 & 32 & 49,2 \\
\hline Praha - Jízdárna & 47 & 33 & 70,2 & 17 & 51,5 & 16 & 48,5 & 14 & 29,8 & 4 & 28,6 & 10 & 71,4 \\
\hline Praha - Triangl & 53 & 30 & 56,6 & 10 & 35,7 & 18 & 64,3 & 23 & 43,4 & 8 & 34,8 & 15 & 65,2 \\
\hline Žalov - cihelna & 63 & 37 & 58,7 & 29 & 78,4 & 8 & 21,6 & 26 & 41,3 & 16 & 61,5 & 10 & 38,5 \\
\hline $\begin{array}{l}\text { Žalov - } \\
\text { Na Panenské }\end{array}$ & 43 & 28 & 65,1 & 21 & 75 & 7 & 25 & 15 & 34,9 & 11 & 73,3 & 4 & 26,7 \\
\hline Klecany I & 71 & 39 & 54,3 & 28 & 71,8 & 11 & 28,9 & 32 & 45,7 & 15 & 46,9 & 17 & 53,1 \\
\hline Klecany II & 35 & 20 & 57,1 & 8 & 40 & 12 & 60 & 15 & 42,9 & 9 & 60 & 12 & 40 \\
\hline Brandýsek & 56 & 42 & 75 & 18 & 42,9 & 24 & 57,1 & 14 & 25 & 5 & 35,7 & 9 & 64,3 \\
\hline Praha-Motol & 221 & 118 & 53,4 & 49 & 41,5 & 69 & 58,5 & 103 & 46,4 & 32 & 31,1 & 71 & 68,9 \\
\hline
\end{tabular}

Tab. 2. Sledované kategorie na vybraných pohřebištích - souhrny.

Tab. 2. Beobachtete Kategorien auf ausgewählten Gräberfeldern - Zusammenfassungen.

\begin{tabular}{|c|c|c|c|c|c|c|c|c|c|c|c|c|}
\hline & \multicolumn{2}{|c|}{ keramika } & \multicolumn{2}{|c|}{ vědra } & \multicolumn{2}{|c|}{$\begin{array}{c}\text { vejce } \\
+ \text { masitá } \\
\text { strava }\end{array}$} & \multicolumn{2}{|c|}{$\begin{array}{l}\text { zbraň, jiný } \\
\text { milodar }\end{array}$} & \multicolumn{2}{|c|}{ kámen } & \multicolumn{2}{|c|}{$\begin{array}{c}\text { zvláštnosti } \\
\text { uložení }\end{array}$} \\
\hline pohřebiště & dosp. & děti & dosp. & děti & dosp. & děti & dosp. & děti & dosp. & děti & dosp. & děti \\
\hline Praha - Lumbeho z. & 5 & 7 & 3 & 3 & 1 & 5 & 0 & 4 & 16 & 10 & $?$ & 0 \\
\hline Praha - Jízdárna & 3 & 0 & 1 & 1 & 0 & 0 & 0 & 0 & 10 & 6 & 0 & 0 \\
\hline Praha - Triangl & 0 & 1 & 0 & 1 & 0 & 3 & 0 & 0 & 7 & 8 & 0 & 0 \\
\hline Žalov - cihelna & 11 & 9 & 3 & 0 & 1 & 5 & 0 & 0 & 3 & 0 & $?$ & $?$ \\
\hline $\begin{array}{l}\text { Žalov - } \\
\text { Na Panenské }\end{array}$ & 8 & 8 & 5 & $\begin{array}{l}\text { sou- } \\
\text { struž. }\end{array}$ & 1 & 0 & 1 & 0 & 0 & 0 & 1 & $\begin{array}{l}2 \text { ju- } \\
\text { venis }\end{array}$ \\
\hline Klecany I & 6 & 10 & 6 & 2 & $6+4$ & $0+2$ & 2 & 1 & 4 & 3 & 0 & 0 \\
\hline Klecany II & $1 ?$ & 0 & 0 & 0 & 0 & 0 & 0 & 0 & 4 & 6 & 0 & 0 \\
\hline Brandýsek & 6 & 0 & 2 & 0 & 0 & 0 & 3 & 0 & 25 & 8 & $2 ?$ & $1 ?$ \\
\hline Praha-Motol & 12 & $6+1$ & 4 & 0 & 0 & 0 & 0 & 3 & 77 & 50 & $1 ?$ & $1 ?$ \\
\hline
\end{tabular}

\section{Charakteristika jednotlivých pohřebišt' (tab. 1)}

Praha - Lumbeho zahrada Pražského hradu (dále jen Lumbeho zahrada)

Pohřebiště bylo zkoumáno v letech 1972-1976 týmem tehdejšího Archeologického ústavu ČSAV pod vedením Z. Smetánky. Bylo prozkoumáno a očíslováno 137 hrobů, čtyři hroby prribyly při záchranném výzkumu v roce 1987 pod vedením J. Frolíka. Pohřebiště je datováno od konce 9. do počátku 11. století (Frolík 2014, 105).

Po podrobné analýze J. Frolík počítá se 149 jedinci ve 148 hrobech (Frolík 2014, 7). Z nich bylo 84 dospělých a 65 dětí (tamtéž, 41). Mezi dospělými bylo 56 pohřbů s výbavou a 28 bez výbavy, tj. dvě třetiny s výbavou a jedna třetina bez ní. Mezi dětmi byl poměr vyrovnaný 33 hrobů s výbavou a 32 bez výbavy. Z 56 pohřbů dospělých s výbavou jen devět obsahovalo nádobu nebo vejce, což činí 16,1 \% z hrobů dospělých s výbavou a 10,7 \% všech hrobů dospělých, 
zatímco 14 dětských pohřbů (v hrobě 86 bylo vejce i nádoba) ze 32 činí 42,4 \%, resp. 21,5 \% ze všech dětí; započítáme-li jako milodary hřeben (hrob 48), miniaturní sekerky (hroby 44 a 74B) a rolničky (hrob 78), bude jejich poměr ještě vyšší. Podle datování hrobů dle J. Frolíka (2014, 62-63) jich do staršího horizontu pohřbívání, z konce 9. až první poloviny 10. století, patří sedm (hrob 90 dospělého, děti v hrobech 21, 29, 30, 46, 52, 86), do středního ze druhé čtvrtiny až konce 10. století (tamtéž, obr. 1/49) jich zařadil pět (hroby dospělých $37,58,72$, hroby dětí 93, 96). ${ }^{4}$ Vědérka byla rovnoměrně rozdělena mezi dospělé (hroby 11, 22, 36) a děti (hroby 29, 43, 58), avšak sama o sobě nejsou přsněji datovatelná. Do staršího horizontu lze bezpečně klást pouze vědra v hrobě 11 podle záušnic $\mathrm{s}$ očkem a v hrobech 29 a 58 podle keramiky. $Z$ hrobů, v nichž byly nalezeny skořápky vejce (v dětských hrobech 47, 84, 86, 88 a 104 a v hrobě staré ženy 28), je datovatelný do staršího horizontu hrob 86 podle keramiky a šperků (originální náušnice s bubínkem a háčkem). Pro hroby 104 (kromě vejce nůž, záušnice s očkem, gombíky, hrozníčkovitá náušnice) a 84 (jeden $\mathrm{z}$ nejbohatších, kombinace šperků velkomoravské tradice a esovitých záušnic) platí konstatování J. Frolíka, že šperky vycházející z velkomoravské tradice, ale s novými prvky byly zřejmě ukládány v delším časovém rozptylu (2014, 73-74). O magicky ochranné funkci se uvažuje u rolniček (Bronicka-Rauhut 1998, 31), jež byly nalezeny v dětských hrobech 43 a 74B v poloze u boku a v počtu tří kusů v hrobě 78 za hlavou (Frolík-Smetánka 2014, 138 podle vyobrazené nálezové dokumentace mohly být našité na kapuci nebo navlečené na šn̆ůrce provlečené čepečkem). Všechny tři děti zemřely ve věku 2-3,5 roku. Hrob 74B je důležitý jednak kvůli své poloze - jde o hrob v subpozici pod hrobem 74A, jednak kvůli výbavě - obojí ho řadí do staršího horizontu. Dítě v něm mělo vedle rolničky také drobný skleněný závěsek (nabízí se myšlenka, že smyslem bylo, aby o sebe oba předměty na šñurce u pasu cinkaly), nůž a miniaturní železnou sekerku, součástí jeho oděvu byly dva měděné zlacené gombíky. Miniaturní sekerky z hrobu 74B i z hrobu 44 (dvouleté dítě) klade J. Frolík do staršího horizontu a pár miniaturních ostruh v hrobě 65 (trríleté dítě) napodobuje ostruhy s dlouhým bodcem, běžné v 10. století (Frolík 2014, 60). K neobvyklým přídavkům patří hřeben v hrobě 48 (devítileté dítě) položený u nohou, tedy umístěný stejně, jako bývají nádoby a vejce.

A konečně ke speciálnímu druhu výbavy patří jednak obolus mrtvého v podobě denáru knížete Jaromíra v hrobě $125,{ }^{5}$ jednak lidské zuby v hrobě 51 , jenž je datován do staršího horizontu podle přítomnosti záušnic s očky (Frolík-Smetánka 2014, 104-105). Zuby byly pravděpodobně uloženy ve váčku u pasu pohřbené ženy a nelze je pokládat za zvláštní hrobový přídavek, spíše charakterizovaly svou majitelku (Smetánka 1988).

Výskyt kamenů v hrobech podrobně vyhodnotil J. Frolík (2014, 26-28). Stačí zopakovat, že jednotlivé kameny v různých polohách ležely v 17 hrobech, neúplné obložení bylo v pěti hrobech, kamenný zával ve čtyřech hrobech. $Z$ nich můžeme podle př́tomné výbavy zařadit hrob 76 do první poloviny 10. století (Frolík 2014, 60) a hroby 37, 103, 123 s esovitými záušnicemi a 125 do mladšího horizontu (viz výše). Mezi „závaly“, které J. Frolík považuje za opatření proti revenanci, jsou započítány hroby 3, 9, 15 a $50(2014,26)$. Avšak dětský hrob 15 , v němž vztyčené ploché kameny tvoří útvar na způsob sarkofágu (Frolík-Smetánka 2014, 63), je posléze oprávněně počítán k hrobům, jejichž úprava jámy dokládá mimořádné postavení zemřelého (Frolík 2014, 104). Na základě jeho výbavy segmentovanými korálky v kombinaci s jantarovým kusem lze vyloučit, že by patřil k mladšímu horizontu pohřbů. Naopak ženský hrob 9 dle dokumentace (Frolík-Smetánka 2014, 56-57) působí spíše dojmem, že některé kameny z obložení se prostě sesunuly nad kostru po zetlení měkkých tělních tkání. Blokační význam rozmístění kamenů proti revenantovi připouštím u hrobů 3 a 5: jedinec věkové kategorie senilis pohřbený v hrobě 3, podle záušnice s očkem u lebky

\footnotetext{
4 J. Frolík (2014, 61-64) uvádí ve výčtu hrobů s keramikou také H 97: v něm je však jen malý střep, který je spíše jen náhodnou př́měsí. V případě H 30 se jedná o dva zlomky z jedné nádoby, z nichž jeden zůstal u nohou, proto se prrikláním k možnosti, že šlo o intencionálně rozbitou nádobu. Za záměrný př́idavek pokládá J. Frolík ještě střep z masivní zásobnice v H 120, poškozeném novověkou zdí, který by tak patřil až do 11. století; avšak střep ležel v atypické poloze u hlavy, jeho interpretace je proto podle mého názoru sporná.

5 Obolus mrtvého jako speciální případ hrobové výbavy byl předmětem zájmu četných badatelů, starší výklady kriticky přehodnotil J. Klápště (1999). Není však předmětem tohoto článku ze dvou důvodů: jednak se časově vymyká ze stanoveného rámce, jednak jde o ojedinělý případ mezi všemi hroby na všech pojednávaných pohřebištích.
} 
zřejmě žena, byl zavalen kameny na horní polovině těla a nad chodidly; dítě bez výbavy v hrobě 50 bylo uloženo na prkně a zakryto třemi kameny. Mezi hroby s kamenem byly jak hroby bez výbavy, tak i s bohatou výbavou, ze starší etapy pohřbívání i z nejmladší (Frolík 2014, 28).

Na základě dokumentace Z. Smetánky to vypadá, jako by na pohřebišti byly postmortální zásahy častým jevem: oddělená lebka a mandibula v hrobech 1, 8, 51 a 95, posunutá mandibula a krční obratle v hrobech 22, 23, 32, 60, 106 a 133B, někdy kombinované se zásahem na nohách, chybějící lebka v hrobě 56, přičemž mandibula v hrobě zůstala (Frolík 2014, 38-39), dislokace lebky, mandibuly a krčních obratlů v hrobě 9 (tamtéž, 27). Až na hrob 106 jde o hroby dospělých osob, hroby 1, 51 a 106 jsou datovány do staršího horizontu, hrob 23 do mladšího a ostatní byly bez datovatelné výbavy. Prohlížíme-li však publikovanou dokumentaci (Frolík-Smetánka 2014, $49,56,71,73,84,104,118,163,177,207)$, vnucuje se myšlenka, že většina dislokací byla vysvětlována jako protivampyrické zásahy prostě proto, že v době výzkumu nebyly mezi archeology známy vlivy tafonomických procesů, zejména při pohřbech v rakvi (Černý 1995; Čech-Černý 1996; Prokeš 2007), ani se nevěnovala pozornost možnosti narušení bioturbací (Mazuch-Hladík-Skopal 2017, 104-121).

\section{Praha - Pražský hrad, pohřebiště Jizdárna (dále jen Jízdárna)}

Ze všech hrobů $\mathrm{v}$ areálu nalezených je k analýze použitelný hrob $1 / 47$, některé hroby $\mathrm{z}$ výzkumu I. Borkovského v letech 1951-1952 a skupinka hrobů ze záchranného výzkumu v letech 1982-1983. Pohřebiště je K. Tomkovou uváděno jako východní skupina jednoho rozsáhlého pohřebiště v zahradách Pražského hradu (2005b, 388), J. Frolík ji považuje za tzv. oddělené pohřebiště (2014, 7-10). Pohřebiště Jízdárna je datováno od poslední třetiny 9. do počátku 11. století (Tomková 2005b, 387).

Z pohřebiště Jízdárna celkem beru v úvahu 47 hrobů, u nichž bylo zjistitelné základní antropologické rozdělení na dospělé a děti. $Z$ nich bylo 33 dospělých a 14 dětí, podíl dětských hrobů je tedy výrazně menší než na sousedním pohřebišti v Lumbeho zahradě. $Z$ hrobů dospělých bylo 17 s výbavou a 16 bez výbavy, z dětských byly s výbavou pouhé čtyři hroby a deset jich bylo bez výbavy. Kromě šperků a nožů se ve třech hrobech dospělých objevila keramická nádoba (hroby 8/51, 15/51 a 1/82, Tomková 2006, 27, 30 a 48) a v jednom vědérko (hrob 28/51, tamtéž, 34), $\mathrm{v}$ dětských hrobech bylo vědérko nalezeno v hrobě $1 / 47$ (tamtéž, 22). K. Tomková uvádí kamenné obložení úplné nebo částečné ve čtyřech hrobech (hroby 24/51, 30/51, 90/51, 91/51, tamtéž 2006, obr. 2/12, 13), jednotlivé kameny zpravidla za hlavou v sedmi hrobech (hroby 7/51, 70/51, 89/51, 92/51, 96b/51, 100/51, 101/51, tamtéž, 26, 37, 39, 42, 43, 44) a zaznamenává př́itomnost kamenů v částečně odbagrovaných hrobech 102/51, 103/51 a 104/51 (tamtéž, 44). Dětský pohřeb 93/51 byl kameny obložený a překrytý do podoby charakterizované K. Tomkovou dokonce jako „předrománská hrobka“ (2005, tab. 3), v mužském hrobě 4/82 stály šikmo postavené kameny na prkně kryjícím tělo (Tomková 2006, 51). Z hrobů s kameny pouze ve dvou byla nalezena osobní výbava v podobě esovitých záušnic (Tomková 2005b, tab. 2, obr. 4). V dětském hrobě $7 / 51$ to byly záušnice nejmenší, o průměrech 9-15 mm a síle drátku 1-1,5 mm, jediná záušnice v ženském hrobě $96 \mathrm{~b} / 51$ měla průměr $10-12 \mathrm{~mm}$ a sílu drátku $1,5 \mathrm{~mm}$, patří tedy také $\mathrm{k}$ nejmenším a nejstarším (Tomková 2005a, 27, 42). Žádné pohřby, jež by bylo možno bez zpochybnění považovat za druh protivampyrického zásahu, nejsou registrovány (Tomková 2005, 180).

Vzhledem k velkému poškození hrobů stavební činností toto pohřebiště nedává dost podkladů k podrobnějšímu zkoumání $z$ hlediska postupu christianizace, je však důležité pro srovnání se sousedním pohřebištěm v Lumbeho zahradě.

\section{Praha-Střešovice, poloha Triangl (dále jen Triangl)}

Pohřebiště bylo prozkoumáno v roce 2012 během záchranného výzkumu vedeného D. Frolíkovou (Frolíková-Kaliszová 2014). Šlo o část pohřebiště ve strahovské cihelně, jehož části položené 
níže po svahu byly zničeny již v 19. století (Tomková 2006, 105-114). Pohřebiště je datováno do 10. století (Frolíková 2013, 27).

Ze 49 hrobových jam byly vyzvednuty určitelné pozůstatky 30 dospělých ve 27 hrobech a 23 dětí ve 22 hrobech. Zastoupení pohřbů dospělých a dětí je téměř stejné jako na pohřebišti v Lumbeho zahradě. Poměr hrobů s výbavou a bez výbavy u dospělých a dětí je srovnatelný zhruba třetina hrobů je s výbavou a dvě třetiny jsou bez výbavy. $Z$ osmi dětských pohřbů s výbavou bylo v hrobě 25 vědro, v hrobě 26 hrnec a vajićko, v hrobě 38 vajíčko a v hrobě 42 po jednom vajíčku u každé nohy, zatímco v hrobech dospělých se žádné nádoby, zvířecí kosti či vajíčka nenašly.

Všechny abnormality v poloze koster $\mathrm{v}$ hrobech jsou vysvětlitelné bud' činností zemních živočichů (rozpoznané nory v hrobech 10, 28 a 36), nebo jako posun v primárním dutém prostoru rakve u mírných odchylek jako sklon lebky nebo posun kostí končetin. Zjištěné uložení kostí ze staršího narušeného hrobu v novém hrobě nelze považovat za nic jiného než projev piety. Postmortální zásahy nebo explicitní zatížení částí těla mrtvého kameny nebyly zjištěny, pokud v některém hrobě byly kameny nad kostrou, šlo vždy o naklonění kamene/kamenů původně postavených mezi tělem mrtvého a stěnou hrobové jámy.

Jednotlivé kameny byly rozmístěny v dětských hrobech 18 a 33, shluky kamenů byly objeveny v nohách hrobů 25 a 26 (oba pohřby dětské) a 29 (ženský) porušených výkopem I. Borkovského. Souvislé kamenné obložení se vyskytlo u tří hrobů dospělých (hroby $4,5,30$ ) a u dětského hrobu 10, u dětského dvojhrobu 7 šlo o obložení a překrytí. Jednotlivé kameny „těsnící“ prostor mezi rakví a stěnou hrobové jámy byly použity v dětském hrobě 42 a v hrobech dospělých 44 a 48, stély za hlavou a nohama rakve stály v hrobě dospělého 20 , v hrobě dospělého 45 byly kameny rozmístěny na vyvýšeném schůdku po levé straně hrobové jámy.

Roztoky-Žalov - cihelna B (dále jen Žalov-cihelna)

Pohřebiště ničené cihelnou nejpozději od roku 1840 rozdělila K. Tomková na části A a B $(2020$, 28-29). K analýze jsou použitelné hroby z pohřebiště Žalov-cihelna B ze záchranných výzkumů I. Borkovského v letech 1949, 1952 a 1957. Pohřebiště má řadové uspořádání s velkými rozestupy (Tomková 2020, obr. 11) a pohřbívalo se na něm od závěru 9. asi do přelomu 10. a 11. století (tamtéž, 268).

Podíl dětských hrobů na pohřebišti činí 41,3 \% (přičemž ale mnohé dětské hroby nebyly rozeznány, Tomková 2020,73). Procento hrobů dospělých s výbavou je nejvyšší ze všech sledovaných pohřebišt' a poměr je nadpoloviční i u dětských hrobů. Relativně vysoký je i počet hrobů s keramikou - láhev či hrnec byly vloženy do deseti hrobů dospělých (hroby $6,13,21$, $34,36,41,45,52,54,60$ ) a deseti dětských (hroby $9,10,19,27,30,47,56,63,64,66$ ), ve dvou hrobech dospělých bylo přiloženo vědro (hroby 26,41 ), z toho v jednom hrobě byla jak keramika, tak vědro. Vejce se vyskytlo v jednom hrobě dospělého spolu s nádobou (hrob 6 ) a v pěti dětských hrobech (hroby 17, 19, 20,64, 66), jednou spolu s nádobou a jednou v počtu dvou kusů. Další vejce bylo v hrobě 50, u kterého se nedochovala kostra, a není tudíž zřejmé, zda patřil dospělému jedinci nebo dítěti (velikost hrobové jámy je hraniční). Roztřídění keramiky do technologických skupin A-F vedlo K. Tomkovou k poznatku, že keramické skupiny nejsou samy o sobě chronologickým kritériem; avšak po ztotožnění skupin s horizonty LH 1 až LH 4 definovanými na základě masy keramiky ze sídlištních vrstev hradiště Levý Hradec (Tomková 2001, 82-98) vychází, že se na pohřebišti nacházejí hroby s keramikou datovatelnou od jeho počátků až ke konci 10. století (Tomková 2020, 109-121). Nevyskytuje se nejstarší skupina $\mathrm{A}$, nejvíce nádob patří do skupiny $\mathrm{C}$, do nejmladší skupiny $\mathrm{D}$ patří nádoba $\mathrm{z}$ jediného hrobu 21.

Odchylky od pravidelné polohy nejsou na pohřebišti jako celku hodnotitelné z důvodu nedostatečné terénní dokumentace (Tomková 2020,71). Použití kamene je vzácné, K. Tomková uvádí pouhé tř̌i př́ípady výskytu jednotlivých kamenů, vesměs v hrobech dospělých $(2020,58)$. 


\section{Roztoky-Žalov - Na Panenské (dále jen Žalov - Na Panenské)}

Výzkum v lokalitě, na níž dodnes probíhá postupná výstavba rodinných domků, probíhal od roku 2003 s přestávkami do roku 2011; jako dodatek je v publikaci zařazen malý záchranný výzkum z roku 2013 (Brejcha-Tomková 2020). Pohřebiště datuje K. Tomková od druhé poloviny 9. století do první třetiny 10 . století (Tomková 2020,288 ) a hodnotí je jako pohřebiště s nepravidelným, volným rozmístěním hrobů na ploše (tamtéž, 43, 45).

Celkem 43 jedinců bylo pohřbených ve 43 hrobech (jeden hrob prázdný, jeden dvojhrob), z toho 28 dospělých a 15 dětí. Procento hrobů s výbavou je v obou kategoriích vysoké, až $75 \%$. Jeden hrob dospělého obsahoval sekeru (hrob 9), keramika byla nalezena v osmi hrobech dospělých (hroby 4, 6, 8, 13, 15a, 22, 28, 32) a osmi dětských (hroby 14, 16, 33, 34, 35, 38, 41 a v hrobě 39 dvě nádoby), vědérko $v$ pěti hrobech dospělých (hroby $9,10,24,29,46$ ), asi soustružená nádobka s bronzovými kováními v dětském hrobě 41 (Tomková 2020, 132). Vaječné skořápky byly nalezeny pouze $\mathrm{v}$ ženském hrobě 22 (spolu se spodkem nádoby). Zajímavé je, že výskyt keramických skupin na obou žalovských pohřebištích se poněkud liší: keramika skupiny B se vyskytuje na obou pohřebištích, Na Panenské však chybí typologicky mladší skupiny, a naopak se zde objevují nejstarší hrnce středohradištní skupiny A.

Zvláštní poloha se vyskytla u jedinců v hrobech 1 - žena na břiše, 12 - dospívající v poloze na boku a 27 - dospívající na boku. Pro většinu menších odchylek od pravidelné polohy naznak nachází K. Tomková vysvětlení v malé velikosti hrobové jámy (včetně hrobů 1 a 27), bioturbací, tlením v dutém prostoru, posunech podložky po zetlení apod. (Tomková 2020, 76). Kámen eviduje K. Tomková pouze v zásypech některých hrobových jam $(2020,258)$.

\section{Klecany II - pohřebiště na hradišti (dále jen Klecany II)}

Pohřebiště bylo zkoumáno v roce 2000 ve spolupráci I. Krutiny z Okresního muzea Praha-východ a N. Profantové z Archeologického ústavu AV ČR v Praze (Krutina-Profantová 2001). Pohřebiště jako celek je datováno do intervalu od počátku 10. po konec 10. století (Profantová 2011b, 209).

Ze 40 číslovaných hrobů bylo 35 pohřbů dokumentováno v takovém stavu zachovalosti, že je možno je použít při analýze. Pohřby dospělých převažovaly nad pohřby dětí, poměr mužů a žen byl vyrovnaný, dětských pohřbů bylo více s výbavou než bez ní, zatímco u dospělých tomu bylo naopak. Co se týče milodarů, jen v jediném hrobě 23 (dospělá žena) bylo nalezeno dno nádoby za lebkou, a je tedy otázka, zda šlo o záměrné uložení v tak netypické poloze, nebo jde jen o náhodně spadlý zlomek při zahazování hrobu. V dětských hrobech nebyl nalezen žádný milodar. Vzhledem $\mathrm{k}$ tomu, že $\mathrm{v}$ žádném hrobě nebyly zaznamenány ani skořápky vejce, lze říci, že na tomto pohřebišti dosud nebyl nalezen žádný milodar. Nebyla shledána ani žádná abnormální odchylka od pravidelné polohy mrtvého. Kameny $\mathrm{v}$ hrobě byly objeveny $\mathrm{v}$ pěti případech, nikdy nešlo o obložení; z nich datovatelné jsou dva hroby, v nichž měla pohřbená esovité záušnice, oba hroby N. Profantová klade do mladší fáze pohřebiště (2011a, 160).

\section{Klecany I-pohřebiště v zámecké (nyní skautské) zahradě (dále jen Klecany I)}

Jednotlivé hroby byly zachraňovány postupně již od počátku 20. století, systematicky lokalitu sledovala a prováděla záchranné výzkumy od roku 2005 M. Profantová z pražského Archeologického ústavu. Pohřebiště „se začiná použivat o málo dřive než pohřebiště Klecany II“ (Profantová 2011, 124), tedy nejpozději od třetí třetiny 9. století (Profantová 2011b, 209). Končí pravděpodobně v první polovině 11. století (tamtéž, 126).

Na pohřebišti bylo v 70 hrobových jamách pohřbeno 39 dospělých jedinců, mezi nimiž vysoce převažovaly ženy (22 žen a 8 mužů), osm antropologicky ani archeologicky nerozlišitelných dospělých, jeden dospívající a 32 dětí včetně kategorie novorozenec/nenarozený plod. Procento hrobů dospělých s výbavou je vysoké, 71,8 \% (což ovšem ovlivnil nepoměr mužských pohřbů vůči 
ženským), zatímco u dětí je poměr vyrovnaný. V šesti hrobech dospělých $(1 / 37,15 / 05,27 / 05,57 / 05$, $68 / 07,89 / 08)$ a v deseti dětských (4/F, 4/37, 31/05, 43/05, 49/05, 58/05, 60/06, 64/06, 83/08, 84/08) byla vložena keramická nádoba, vědro v šesti hrobech dospělých $(2 / 94,22 / 05,54 / 05,66 / 06,76 / 07$, $89 / 08)$ a jen ve dvou dětských $(31 / 05,48 / 05)$. Dítě v hrobě 84/08 mělo vedle nádoby ještě rolničku. Vejce se vyskytlo v pěti hrobech dospělých (hroby 15/05, 23/05, 25/05, 54/05 a 89/08) a rovněž v šesti dětských hrobech $(43 / 05,47 / 05,49 / 05,64 / 07,90 / 08,92 / 08)$, k tomu v dětských hrobech $60 / 06$ a 64/06 byly také kosti mladé slepice. V hrobech dospělých byly vedle kurů v hrobech $3 / 37$ a 68/07 také žebra z prasat v hrobech 54/05 a 76/07 (Kyselý 2010, 25-26). Na tomto pohřebišti byly také pohřby se zbraněmi, a to se sekerou v hrobě $22 / 05$ a sekerou a šipkami v hrobě $76 / 07$, obojí byly hroby dospělých a N. Profantová je klade do staršího horizontu $(2011,74)$. Více milodarů bylo objeveno ve dvou hrobech dospělých (89/08 vědro, hrnec a kus vaječné skořápky; 76/07 zbraně, vědro a zvířecí žebra) a čtyřech hrobech dětí (hrnec a vejce 43/05, 49/05, 64/06, hrnec a rolnička v 84/08). Pečlivým rozborem nálezů N. Profantová rozdělila pohřebiště na starší horizont, který klade do rozmezí let 860-935 (2011, 74-95), s velkomoravskými vlivy projevujícími se hlavně ve špercích, a na mladší horizont, v němž už byly hroby bez výbavy; několik hrobů řadí do přechodného horizontu. Hroby staršího horizontu 1/37, 4/F, 4/37, 22/05, 27/05, 28/05, 31/05, 43/05, 49/05, 53/05, 54/06, 60/06, 64/06, 66/06, 68/06, 74/07, 76/07, 83/08, 84/08, 89/08 jsou datované šperky a/nebo typem keramiky (Profantová 2011, 57-95); přiřadila bych k nim i hrob 15/05 na základě tvaru okraje a výzdoby keramických zlomků (Profantová-Krutina 2010, tab. 15). Ze všech hrobů staršího horizontu jen dva neobsahují pravé milodary (hroby 28 a 53). Do přechodného horizontu jsou kladeny hroby 22/05 a 89/08, v absolutních datech 900-940/946 (Profantová 2011, 96). Mladší horizont je charakterizován esovitými záušnicemi (hroby 13/05, 20/05, 25/05, 32A/05, 70/07 a 71/07 nebo keramikou s kalichovitým okrajem 57/05, 58/05 (tamtéž, 96, 57).

Kamenné obložení bylo zaznamenáno u hrobů 1/37, 5/94, 70/07 a 71/07, kamenný překryv až kamenná skř́iňka u dětských hrobů 59/06 (datovaný C14 do širokého intervalu před r. 1015, Profantová 2011, tab. 7/24) a 71A/07; kamenná stéla v dětském hrobě 48/05 s dřevěnou nádobkou a v dětském hrobě 49/05. Jednotlivé kameny se vyskytly ještě v dětských hrobech 30/05 a 46/05. Celkem jde o devět hrobů (včetně jednoho dvojhrobu) z celkových 95 číslovaných hrobů (Profantová 2011, tab. 7/23). N. Profantová klade hroby s kamennou úpravou do mladší a nejmladší fáze pohřebiště, absolutně od druhé třetiny 10. století (Profantová 2011, 48).

Třebusice / Brandýsek (dále používám v prvotní publikaci zavedený název Brandýsek)

Polykulturní pohřebiště (číselná řada zahrnovala i pravěké hroby) bylo zkoumáno v letech 1955-1958 pod vedením O. Kytlicové z Archeologického ústavu v Praze (1968). Na rozdíl od O. Kytlicové považuji interval, do nějž kladla dobu pohřbívání v Třebusicích-Brandýsku, za př́liš široký a jeho odůvodnění typologií nepočetné keramiky slabě podložené. Jeho počátek tak můžeme posunout ze „,kklonku 8., spišse však průběhu 9.“ (Kytlicová 1968, 245) století nejméně do druhé poloviny, pravděpodobněji až na samý konec 9 . století. Vzhledem k výskytu esovitých záušnic bych jeho ukončení ,ještě v průběhu 10. stoleti" (tamtéž, 246) upřesnila na průběh druhé poloviny 10. století.

Raně středověkých hrobů bylo odkryto 56 , z nichž bylo 42 dospělých a 14 dětských (hroby 44, 47, 52 a 59 označené v publikaci „,chlapec“, „divka“ nebo antropologicky neurčené jsem na základě délky hrobové jámy nad $200 \mathrm{~cm}$ přiřadila $\mathrm{k}$ dospělým, hrob 55 př́i délce pod $170 \mathrm{~cm}$ $\mathrm{k}$ dětem). Hroby bez výbavy převažují u dospělých i dětí. Vejce ani zvířecí kosti nebyly v hrobech rozpoznány, nádoba se objevila $v$ šesti hrobech dospělých $(11,13,28,29,39,60)$, vědro ve dvou $(6,14 a)$. V hrobě 43 měl zemřelý přiloženou šipku, v hrobě 44 šipku, ocílku a dvě dláta (Kytlicová 1968, 210), v hrobě 79 zase srp. Důležité pro zkoumání projevů christianizace je z hlediska chronologie to, že ženy pohřbené s esovitými záušnicemi neměly v hrobě vloženu nádobu nebo jiný milodar, s výjimkou hrobu 60 (tamtéž, 242).

Kámen byl použit celkem ve 33 hrobech z 54, k čemuž O. Kytlicová uvádí, že v nejstarší severovýchodní části pohřebiště je nápadné vzácné užití kamene, většina hrobů tam byla bez 
kamenů, „,nebo byl v hrobě zjištěn volně ležici menši kámen, který se mohl dostat do hrobu i s násypem“ (Kytlicová 1968, 230). Pravidelný výskyt kamenů mapuje v mladší, řadové části pohřebiště (tamtéž, obr. 41) a úplný kamenný zával byl zjištěn v hrobě 79 ležícím v nejmladší, západní části pohřebiště (tamtéž, 231). Rozebírá př́ípady kamenného překrytí části kostry, které považuje za protivampyrické opatření. Avšak u hrobů 9, 45 a 49 (tamtéž 968, obr. 19, 230) zůstává možnost spadnutí kamenů původně umístěných u stěn hrobové jámy nad kostru, jako záměr vypadá položení jediného velkého kamene nad hlavu mrtvého v hrobě 57 (tamtéž 1968, obr. 24). Hrob 79 kameny obložený i překrytý připouští dvojí interpretaci, bud' jako protivampyrické opatření, nebo jako záměr vybudovat něco jako kamennou hrobku (tamtéž 1968, obr. 26), zatímco dětský pohřeb 33a v kamenné schránce je zřetelně výrazem piety, nebot' i další pohřby 33b a 33c v téže hrobové jámě jsou částečně obloženy kameny (tamtéž 1968, obr. 15).

Závažné odchylky od pravidelné polohy byly zaregistrovány v šesti hrobech: poloha na břiše v hrobech 7 a 16, lebky koster z hrobů 14b, 14c byly položené mezi nohama kostry 14a, chybějící předloktí kostry v hrobech 11 a 60 , porušená krční páteř a mandibula kostry z hrobu 42 . O. Kytlicová podrobně argumentuje proti možnosti následného pohřbu muže $14 \mathrm{a}, \mathrm{v}$ jehož důsledku by byly odděleny lebky starších pohřbů $14 \mathrm{~b}, 14 \mathrm{c}$ a jejich lebky poté pietně uloženy, čemuž na první pohled napovídá tvar hrobové jámy (Kytlicová 1968, obr. 7). Podle vedoucí výzkumu šlo o současný pohřeb všech tří osob (tamtéž, 237-238). Obě chybějící předloktí pokládá za useknutí ruky jako trest (tamtéž, 236-237); bez antropologického ověření stop na kosti považuji toto tvrzení za předčasné, zetlení některé kosti u jinak zachovalé kostry jsme pozorovali např́íklad na pohřebišti Triangl (v hrobě 30 chybí kosti levého bérce, v hrobě 33 chybí levá lýtková kost a pravá loketní, Frolíková 2013 NZ, 17-18). Žena z hrobu 7 s kůstkami plodu nebo novorozeněte v pánvi, ač uložena na břiše, byla pochována v rakvi; úmrtí asi při porodu snad mohlo být důvodem polohy tváří do země a orientace hrobu JJZ-SSV. Hrob $16 \mathrm{~s}$ mužem položeným na břicho měl také odlišnou orientaci, JZ-SV. Tyto dva hroby snad můžeme považovat za projev ochrany před možným revenantem.

Na pohřebišti se nacházela na jeho severním okraji, pod hrobem 7 bez nálezů a s orientací severojižní, obdélníková jáma hluboká $205 \mathrm{~cm}$ s jámou ve dně, v níž bylo nalezeno koňské kopyto, atypické stř́ipky a střep $\mathrm{z}$ mladší doby římské; prresto autorka výzkumu jámu spojuje s pohřebištěm z 10. století (Kytlicová 1968, 195-196). Z. Krumphanzlová jámu srovnává s jinými jámovými kultovními objekty na slovanských pohřebištích s komentářem, že „to znamená, že pohřebiště prodělávalo asi rozličné duchovní změny“ (1997, 396).

\section{Praha-Motol (dále jen Motol)}

Pohřebiště je známo od roku 1921, kdy byly poprvé zaznamenány nálezy jednotlivých ničených hrobů. Teprve v roce 1935 při záchranném výzkumu Státního archeologického ústavu pod vedením R. Turka bylo dokumentováno 29 hrobů a o 40 let později při záchranném výzkumu Muzea hlavního města Prahy pod vedením J. Kováříka v letech 1975-1976 bylo zdokumentováno dalších 208 hrobů (Kovářík 1991). Pohřebiště začalo být používáno koncem 9. století a s pohřbíváním na něm se skončilo ve druhé polovině 11. století (Kovářík 1991, 80; Frolíková-Kaliszová 2000, 243).

Z celkového počtu 243 známých hrobů bylo pro analýzu použitelných 221 hrobů, v nichž bylo identifikováno v součtu 229 jedinců včetně druhotných pohřbů. Na pohřebišti bylo v kategorii dospělí určeno 119 jedinců, jako děti 103 jedinci (k tomu 6 věkově přesněji neurčených dospívajících). Na rozdíl od všech předešlých toto pohřebiště je větší a také se zde pohřbívalo déle. Kvůli tomu se zde dostáváme do nebezpečí argumentace kruhem: do starší fáze pochovávání jsou hroby řazeny kvůli své výbavě, což svádí k zařazování hrobů bez výbavy do mladších fází. Můžeme se však pokusit vyčlenit jednoznačný počáteční a závěrečný horizont pohřbívání a potom hodnotit většinu hrobů, které spadnou do více než stoletého intervalu mezi nimi. Do nejstaršího horizontu kladl J. Kováŕík hroby 5, 17, 61, 65, 79, 80, 127, 138, 142, 143, 154, 159, 161, 169, 
174, 195 na základě přítomnosti keramiky s jednoduše tvarovaným okrajem, záušnic s očkem, náušnic hrozníčkovitých, s uzlíky na oblouku, se spirálovitě vinutým závěskem, s meandrovitým ukončením, olivovitých korálků nebo vědérka (Kováŕík 1991, 79-80). V jeho výčtu chybí hroby 133, 155 a 44 rovněž se záušnicemi s očkem (Frolíková-Kaliszová 2000, obr. 5). Naopak pouhá přítomnost vědérka nemá jednoznačný chronologický význam: v hrobě 79 byly pouze dva zlomky z obručí a jeden z rukojeti uložené atypicky u levého boku, zatímco kameny rozprostřené nad kostrou jsou charakteristické spíše pro mladší fáze pohřbívání, v hrobě 127 se v původní poloze zachovalo jen kování vědra a kameny za nohama (Kováŕík 1991, 98-99, tab. 40/127). Do staršího horizontu pohřbívání, datovaného od konce 9. století (tamtéž, 80) do třetiny 10. století (Frolíková-Kaliszová 2000, 239), tedy nesporně patří 17 hrobů, do nichž bylo vloženo šest nádob a tři vědra, což znamená nadpoloviční počet hrobů s milodary. Ve starším horizontu je velmi malý počet pohřbených dětí, jenom čtyři, a také počet hrobů s kamenem v hrobové jámě je malý, v pěti hrobech byl nalezen jeden nebo dva kamínky, pouze porušený hrob 142 byl překryt kameny (tamtéž, tab. 1). K nejmladším pohřbům patř́ ženské hroby 9 a 16 s esovitými záušnicemi velkých průměrů plátovanými stříbrem (Kováŕík 1991, 80), nad nimiž se nacházel dětský hrob 14, a také ženské hroby 203 a XXIV, k nimž na základě sousedící polohy a shodné orientace i hloubky patrně můžeme přiřadit přinejmenším mužský a dětský hrob 204 a 205 (Frolíková-Kaliszová 2000, 237).

Ze zbývajících 100 hrobů dospělých, nezařaditelných jednoznačně do nejstaršího nebo nejmladšího horizontu pohřbívání, má výbavu 31 hrobů, z 97 dětských 26, z nich jen deset dospělých má jako prrídavek keramickou nádobu nebo vědro a pět dětí keramickou nádobu (v hrobě XVII byly dvě nádoby). $Z$ dalších přídavků dostalo dítě v hrobě 184 rolničku, v dětských hrobech 107 a 130 byly u žeber nalezeny zlomek železné jehly a železný háček (Frolíková-Kaliszová 2000, tab. 1). K tomu v hrobě 175 mělo dítě misku nikoliv jako nádobu, ale dnem vzhůru položenou namísto jednoho z kamenů obložení (tamtéž, 234). Na motolském pohřebišti nebyly rozpoznány vaječné skořápky, což ovšem neznamená, že nebyly do hrobů vůbec přikládány. Mezi nejbohatší patřily hroby dospívajících jedinců: 168 a 200 dívek, XIII chlapce s opačnou orientací.

Kritické přehodnocení si zasluhují případy ,protivampyrických“ zásahů na kostrách. J. Kováŕík jich uvádí šest, $\mathrm{k}$ tomu dalších osm př́ípadů zatížení částí těla zemřelého kameny. Dospělí v hrobech 44 a 178 měli lebku převrácenou, avšak v hrobech byly stopy dřeva (Kováŕík 1991, 90, 121-122), mohlo tedy jít o posun v primárním dutém prostoru, případně ještě tlakem hlíny po zetlení rakve. Vyvrácené čelisti a rozvlečené kosti chodidel v hrobě 48, vysekaném ve skále, se šikmým dnem (tamtéž, foto 21), napovídají, že mohlo dojít k bioturbaci, ale v podloží by zvířecí nory nebyly rozeznatelné. Dvouleté dítě v hrobě 174 má levý femur posunut za lebku, avšak tak malou kost mohl posunout i menší živočich (tamtéž, tab. 56).

U hrobů s kameny použitými dle J. Kováŕíka k tzv. protivampyrickým zákrokům (Kovárrík 1991, 29) je třeba poznamenat, že u (většinou recentně porušených) hrobů 45, 49, 53, 125, 142 z dokumentace vyplývá spíše původní obložení a sesunutí některých kamenů teprve tlakem hlíny po zetlení kostry, případně výdřevy (tamtéž, tab. 13, 15, 39, 46, foto 20, 22). U porušeného hrobu 180 jde o shluk kostí překrytých kameny ve střední části, zatímco neporušené nohy nejsou kameny překryté (tamtéž, tab. 58). Zato hrob 99 je vyloženě honosným pohřbem v rakvi s železnými kováními, obložené kameny, z nichž některé se zřítily na tělo po zteření prken, se stélami za hlavou a nohama a pískovcovou deskou-náhrobkem nad zásypem (tamtéž, tab. 32). Pouze ve dvou př́ípadech lze připustit, že by se snad mohlo jednat o opatření proti vstávání z hrobu: v hrobě 191 uložené dítě 9-12 měsíců staré bylo překryto třemi velkými kameny příčně položenými nad hlavou a nohama (tamtéž, tab. 60, foto 76), a v hrobě 127 recentně překopaném je kresebně dokumentována lebka uložená spolu s vědrem u nohou (tamtéž, tab. 40).

Pohřebiště Motol je ze všech vybraných pohřebišt' nejvhodnější ke zkoumání možné korelace použití kamene při úpravě hrobové jámy s postupující christianizací, protože přetrvává až do 11. století. Ve skupině 17 nejstarších hrobů jich bylo 11 bez výskytu kamene, naopak ve skupině sedmi nejmladších hrobů byly kameny ve všech (Frolíková-Kaliszová 2000, tab. 1). 


\section{Srovnávací analýza vybraných pohřebišt'}

Při srovnávání vybraných pohřebišt' musíme brát v úvahu společenské postavení pohřbených. $\mathrm{Z}$ tohoto hlediska bohatstvím uloženým s mrtvými do hrobu jednoznačně vyniká pohřebiště Lumbeho zahrada. Jestliže nejstarší horizont pohřbívání je charakterizován šperky v některých případech přímo moravského původu (Frolík 2014, 98), jde o první generaci pokřtěných. Bohužel, chronologické etapy vyčleněné J. Frolíkem na pohřebišti Lumbeho zahrada jsou samotným autorem označeny jen za pravděpodobné, nebot' mezi starší hroby byly nepravidelně vkládány mladší, úprava jámy dřevem se prostorově prolíná s použitím kamene apod. (tamtéž, 77), takže hroby bez výbavy nelze zařadit do etap pohřbívání. Ani podrobné zkoumání superpozic nebylo v tomto směru přínosné (tamtéž, 12-21). Musíme se tedy spokojit s konstatováním, že milodary v pravém slova smyslu byly dávány do hrobů v malém počtu případů, avšak po celé 10 . století, bez výrazného rozdílu mezi dětmi a dospělými. Totéž platí o použití kamene - nejsou prokazatelné chronologické rozdíly. Tzv. protivampyrické zásahy na kostře jsou zpochybnitelné, opatřením proti revenanci snad mohlo být rozmístění kamenů v pouhých dvou hrobech. Téměř vyrovnaný podíl hrobů dětí a hrobů dospělých kontrastuje s nízkým podílem dětských hrobů na sousedícím, leč výrazně chudším pohřebišti Jízdárna. Je ovšem otázka, nakolik se v tomto směru neblaze projevilo poškození pohřebiště vzhledem $\mathrm{k}$ obvykle mělčím dětským hrobům a horší zachovalosti kostí, a tedy i jejich případnému nerozeznání dělníky. Jinak ovšem nízký počet hrobů s pravými milodary, použití kamene i v hrobech staršího horizontu pohřbívání a ojedinělý pohřeb v neobvyklé poloze plně odpovídají poměrům zjištěným na pohřebišti v Lumbeho zahradě.

Pohřebiště Triangl má poměr pohřbených dětí a dospělých téměř identický s Lumbeho zahradou a vzhledem k násobně menšímu počtu hrobů je odpovídající i malý počet hrobů s milodary. Důležitý rozdíl je v tom, že nádoby i vejce byly nalezeny výhradně v dětských hrobech. Kameny nebyly použity $\mathrm{v}$ žádném ze čtyř nejbohatších hrobů a na tomto pohřebišti vypovídají patrně více o společenském postavení rodin zemřelých než o čemkoliv jiném (Frolíková-Kaliszová 2014, $323)$.

Obě žalovská pohřebiště leží v bezprostředním zázemí přemyslovského hradiště Levý Hradec, obě mají jen malé procento hrobů bez jakékoliv výbavy. Podrobné srovnání vedlo K. Tomkovou k poznatku, že na pohřebišti Žalov - Na Panenské lze pozorovat vazbu pohřbů bez výbavy na odchylky v ritu, nelze však zjistit jedinou př́činu absence výbavy (včetně eroze a pozdějších lidských zásahů, Tomková 2020,274). Zajímavý je rozdíl v počtu vložených vajec do hrobů, nebot' na lépe prozkoumaném pohřebišti Žalov - Na Panenské bylo nalezeno jen jediné. Zatímco keramika byla vkládána do hrobů dospělých i dětí, vědra byla nalezena jen $\mathrm{v}$ hrobech dospělých; naopak z dětského hrobu pochází nález bronzových kování z dřevěné, zřejmě soustružené misky. Je velká škoda, že z pohřebiště Žalov - cihelna A neznáme hrobové celky ani antropologii pohřbených, nebot' nálezy z tohoto pohřebiště jsou bohatší počtem i kvalitou (tamtéž, 284). K. Tomková hledá vliv nastupujícího křestanství na uspořádání pohřebišt’ v tom, že starší pohřebiště Žalov - Na Panenské má nepravidelné rozložení hrobů, zatímco mladší Žalov - cihelna má víceméně řadové uspořádání (tamtéž, 287).

Pohřebiště Klecany II je pohřebištěm, na kterém pohřbívali obyvatelé hradiště Klecany (původní název snad Pravý Hradec jako pravobřežní protějšek Levého Hradce, Profantová 2011b, 210), pohřebiště Klecany I by mělo být srovnatelné s pohřebišti žalovskými. Obě klecanská pohřebiště zachycují rozdíl mezi rituálem lidí pohřbených $\mathrm{v}$ areálu sídla místního pána, na němž lze předpokládat hlubší pochopení křest’anství (díky přítomnosti? nebo návštěvám? kněze), a volnějším pohřebním rituálem lidí pohřbívajících na pohřebišti v zázemí hradiště. Zatímco na pohřebišti Klecany I pozorujeme milodary až asi do poloviny 10. století, hroby na pohřebišti Klecany II jsou od počátku 10. století bez milodarů. Kameny v hrobech se objevují na obou pohřebištích až v jejich mladším horizontu, dle N. Profantové od druhé třetiny 10. století (2011, 126; 2011a, 160). 
Na pohřebišti Brandýsek se ukazuje přechod od hrobů umístěných jednotlivě, s mírně rozkolísanou orientací, v nichž jsou přiloženy nádoby, vědra nebo šipky (Kytlicová 1968, obr. 37, 38), k řadově uspořádaným, shodně orientovaným hrobům, v nichž se vyskytují esovité záušnice (Kytlicová 1968, obr. 39). Hroby tvoří řady běžící západovýchodně a uzavírají na jižní straně volnou plochu o rozměrech $5 \times 4,5 \mathrm{~m}$ (obr. 2). Tato skutečnost podnítila úvahu O. Kytlicové, že tam byla postavena dřevěná svatyně, beze stopy zmizelá $(1968,244)$, jež hrála roli ve změně pohřebních zvyklostí. S alternativním vysvětlením onoho prostoru přišel L. Šmejda. Sestavil celkový plán lokality se všemi dokumentovanými objekty od pravěkých po raný středověk a do jeho digitalizované podoby vynesl hypotetické mohylové náspy nad hroby pravěkých kultur (Šmejda 2001). Centrální volný prostor tak byl nahrazen seskupením mohylových násypů nad třemi hroby kultury zvoncovitých pohárů. Pominu-li skutečnost, že pracuje s chybným předpokladem, že raně středověké hroby byly kopány do přibližně stejné hloubky (míní od povrchu hypotetických mohyl, tamtéž, 507), stojí zde hypotéza proti hypotéze. Při pohledu na celkový plán se však představa dřevěné svatyňky, zvláště vzhledem k severojižní orientaci místa (Frolíková-Kaliszová 1999, 536), jeví méně pravděpodobnou než na výseku z nálezové situace publikovaném O. Kytlicovou. Existenci drobné dřevěné kůlové stavby sloužící jako svého druhu hřbitovní kaple, určené pro pohřební rituál, na hřbitově v Brandýsku nevylučuje J. Mařík (2001).

Pohřebiště Motol mělo nejdelší trvání, také proto se na něm dobře ukazuje rozdíl mezi starším horizontem s milodary, jejich postupným ubýváním, a naopak přibýváním kamenné úpravy $\mathrm{v}$ hrobech. Vidíme situaci obdobnou té z Brandýska: hroby s kameny v jihozápadní části pohřebiště tvoří řady, které lemují okraj prázdné plochy o rozměrech $8 \times 6 \mathrm{~m}$, uprostřed níž jsou uloženy dva dětské hroby bez výbavy (obr. 3). Stejnou orientaci mají nejmladší hroby 203-205 ve skupině severozápadně od volné plochy. Stavbu dřevěné kaple nad oběma dětskými hroby, orientovanými

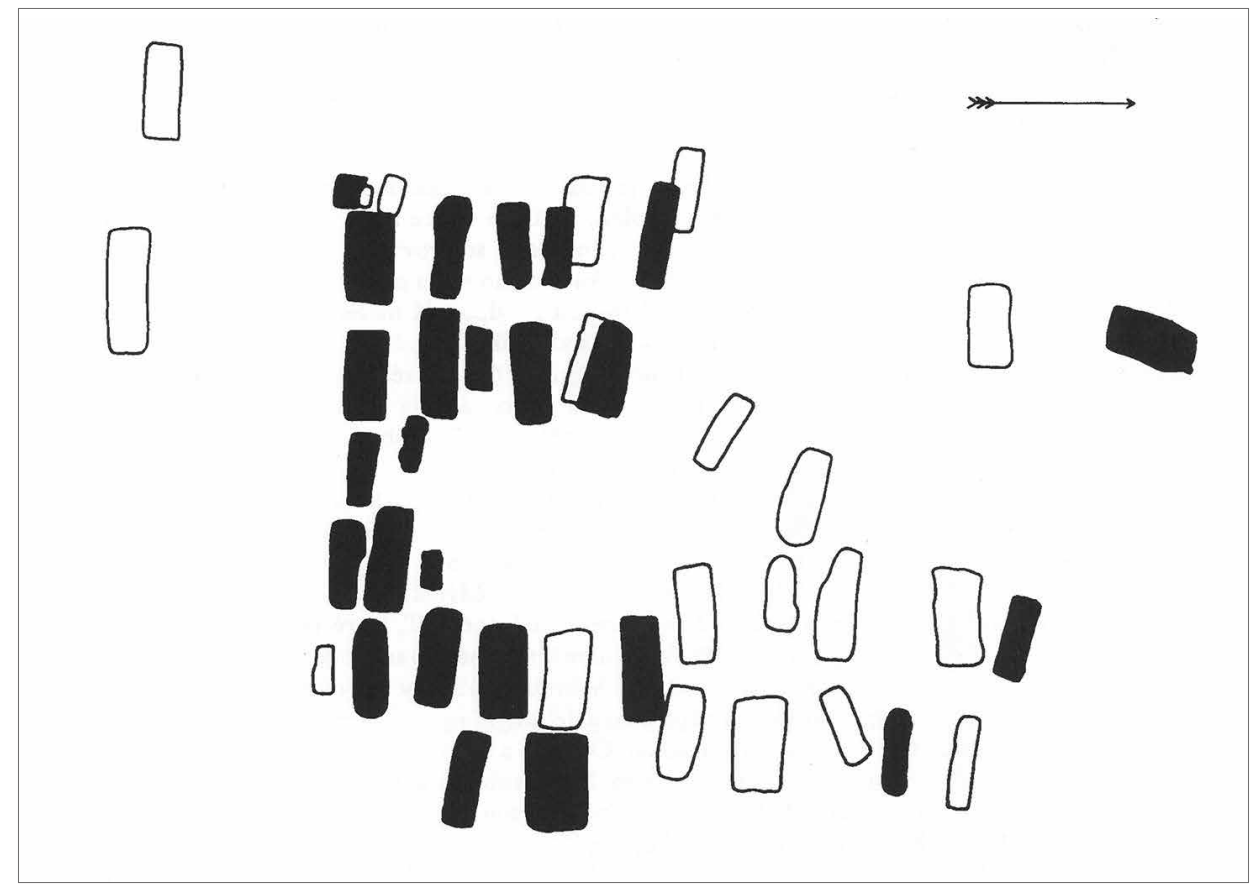

Obr. 2. Část pohřebiště Brandýsek, černě hroby s kameny, uspořádané v řadách jižně od volné plochy (dřevěného kostela?). Podle Kytlicová 1968, obr. 41.

Abb. 2. Teil des Gräberfeldes Brandýsek, schwarz - Gräber mit Steinen in Reihen südlich der Freifläche (Holzkirche?). Nach Kytlicová 1968, Abb. 41. 


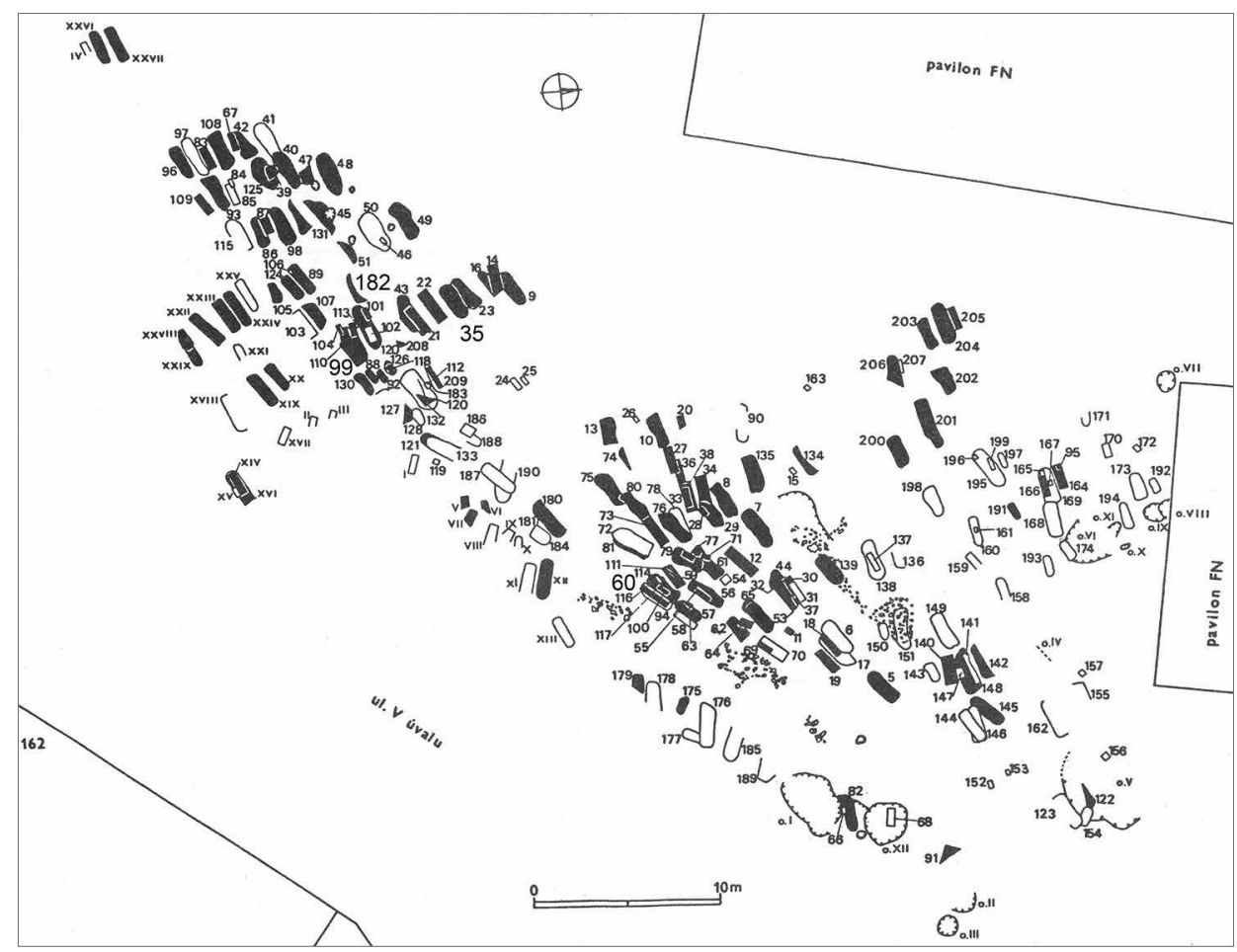

Obr. 3. Pohřebiště Motol, černě hroby s kameny, uspořádané v řadách severozápadně od pravděpodobně dřevěného kostela na prázdné ploše. Čísla 35, 60, 99 jsou čísly hrobů s náhrobním kamenem, v hrobě 182 stál kámen s reliéfem maltézského kříže. Podle Kováŕík 1991, obr. 6, doplněno.

Abb. 3. Gräberfeld Motol, schwarz - Gräber mit Steinen, in Reihen nordwestlich der wahrscheinlichen Holzkirche in der Freifläche. Die Ziffern 35, 60, 99 bezeichnen Gräber mit Grabstein, in Grab 182 stand ein Stein mit dem Relief eines Malteserkreuzes. Nach Kováŕík 1991, Abb. 6, ergänzt.

západ-východ (Frolíková-Kaliszová 1999, 537-538), po níž se v terénu nezachovaly žádné stopy, ovšem nelze datovat přesněji než do průběhu středního horizontu pohřbívání, tj. průběhu druhé poloviny 10. až počátku 11. století. Na kostelním hřbitově pak není udivující výskyt pískovcových náhrobních kamenů v hrobech 35, 60 a 99, jakož i opracovaný pískovec uvnitř hrobové jámy 182 s reliéfem maltézského kříže (Kovářík 1991, 20-21). Idea náhrobního kamene byla na venkovském hřbitově zřejmě uplatněna po vzoru hrobů na Pražském hradě.

\section{Závěr}

V obou tabulkách je vidět obtížnost srovnávání různě velkých, v různé době a kvalitě vykopaných pohřebišt'. První zkoumané kritérium, postupné přibývání počtu pohřbených dětí, je zřetelné pouze na největším a nejdéle trvajícím pohřebišti v Motole, kde je ze 17 hrobů zařazených do nejstaršího časového horizontu pouze necelá čtvrtina dětských, a zároveň je v těchto nejstarších hrobech celá polovina všech nádob. Keramika se objevovala na většině pohřebišt' stejně řídce v hrobech dospělých i dětí, s výjimkou Motola, kde byla častější v hrobech dospělých, a Klecan I, kde byla naopak častěji v dětských hrobech. Vědra byla přikládána většinou dospělým, jenom v Lumbeho zahradě jich bylo nalezeno stejně v hrobech dětí jako dospělých. Klecany I jsou výjimkou také u milodaru vejce, na ostatních pohřebištích byla nalezena převážně v dětských hrobech. Nádoby, vejce i zvířecí kosti byly převážně kladeny $\mathrm{k}$ nohám zemřelého. V souvislosti s ubýváním potravních milodarů 
konstatuje V. Šikulová, že na mladohradištních pohřebištích se v hrobech z masitých milodarů objevují nanejvýš kosti kurů $(1959,105)$. Z devíti zkoumaných pohřebišt' máme masité milodary doloženy v podobě kostí zvířat a drůbeže pouze v Klecanech I. (Kyselý 2011, 25-26). Zbraně v podobě seker nebo šipek jsou doloženy v Brandýsku, Žalově - Na Panenské a Klecanech I, jako miniatury pouze $\mathrm{v}$ dětských hrobech na pohřebišti v Lumbeho zahradě.

Velmi různě se projevuje také použití kamene při úpravě hrobu. Na Žalově je jeho výskyt minimální. V Klecanech i na Trianglu se zdá, že podíl částečného až úplného obložení dna hrobové jámy vzrůstá u mladších pohřbů. Na pohřebištích Lumbeho zahrada a Jízdárna mírně převažuje jejich užití v hrobech dospělých, prričemž používání kamenů od počátku pohřbívání na pohřebištích na dohled kostela Panny Marie a později i kostelů sv. Jiří a sv. Víta by mohlo být vysvětleno př́kladem pohřbů panovníků v kamenných hrobkách. Zato na obou venkovských pohřebištích v Brandýsku i Motole se jeví poměrně výrazný nárůst počtu hrobů s kamenným obložením, stélami nebo dokonce s náhrobky až v mladším horizontu pohřbívání, více v hrobech dospělých než dětských.

Kritické hodnocení ukazuje problematičnost mnoha hrobů, na nichž byla dříve rozpoznávána „protivampyrická opatření“. U starších záchranných výzkumů s neúplnou dokumentací je často těžké rozhodnout, nakolik došlo k posunu částí těla při pohřbu nebo krátce po něm a nakolik při jejich odkrytí/narušení hrobu před příchodem archeologa. Spolehlivé jsou jen údaje z pohřebišt' Žalov - Na Panenské, Triangl, Klecany II a hrobů odkrývaných od roku 2005 v Klecanech I. Jako pravděpodobnější vysvětlení se zdá, že prrípady prokazatelně záměrně nepietního uložení mrtvého či chybějící končetina jsou spíše projevem pohřbu potrestaného zločince, případně sebevraha nebo jinak zavrženého jedince, zvláště pokud má pohřbený u sebe předměty osobního vlastnictví (Mašková 2009, 80-83). Celá problematika víry v revenanci je velmi spletitá, kořeny představy o návratu nebezpečných mrtvých jsou nejasné, písemné prameny se objevují v různých dobách po celé Evropě, ale vždy až v křest’anské společnosti. Nemusí tedy mít nic společného se slovanským pohanstvím, ale především - „pro zvláštnosti nalezené v hrobech obvykle existuji i alternativní vysvětleni" (Braccini 2014, 49).

Svébytným prŕípadem je vložení vejce do hrobu. Jeho význam byl a jistě ještě bude předmětem úvah. Podle L. Niederla vejce v hrobě nepředstavovalo potravu, ale symbol $(1953,130)$. J. Skutil, který se také zabýval symbolikou vejce, upozornil, že vkládat vejce jako obětinu bylo běžné již v antice, včetně keramických či mramorových atrap. Účelem bylo zachovat mrtvému životní sílu; reliktem této ryze pohanské představy jsou dodnes velikonoční kraslice. Konstatoval, že vejce „ještě dnes poživá roli v pověre, kladeni vajec do hrobu je běžné u Cigánü“ (1939, 27). O 15 let později psal V. Hrubý $(1955,101)$, že pohanský zvyk vkládat vejce do hrobu nebyl potlačen ani křestanstvím, „ba nezanikl ještě ani v současné době“. Výskyt keramických vajec vedle ptačích uvádí J. Eisner (1966, 449). Podle B. Dostála je vejce v hrobě symbolem života, resp. vzkřríšení (Dostál 1966, 29). Z. Krumphanzlová (1972, 197-199) opakuje, že vejce byla nalézána v hrobech nejen u Slovanů, ale i u Avarů a Germánů, především u dětí. Jako vysvětlení malého počtu nálezů prŕ́davku vejce $\mathrm{v}$ hrobech upozornila $\mathrm{K}$. Marešová na skutečnost, že v raném středověku musíme počítat s nešlechtěnými plemeny kurů, která snášela pouze v jarních měsících (Marešová 1983, 46-47). Zevrubně se problematice výskytu vejce v hrobě věnoval Z. Smetánka (1988). Dospěl k závěru, že vejce z pohanského symbolu bylo transformováno postupnou akulturací ,ne méně $n e z ̌$ dvě stoleti " trvajícím pozvolným synkretickým procesem v symbol křest’anský (Smetánka 2014, 127-128). Velmi podrobně zpracovala téma výskytu vajec ve středo- až mladohradištních hrobech na území Čech, s přihlédnutím k situaci na Moravě a Slovensku, K. Tomková (2020a). Shrnuje, že je to jev z hlediska četnosti výskytu okrajový, vnitřně variabilní - vložení vejce do hrobu nemuselo mít jednoznačný smysl - a hlavně pro nás těžko postižitelný. Přikláním se k tomu, že nešlo o potravinový milodar, nýbrž o symbol, protože vejce se někdy vyskytuje $\mathrm{v}$ hrobech spolu s nádobou, $\mathrm{v}$ níž zřejmě byla potrava. Na to, jestli bylo vejce přidáno nebo ne, měly zřejmě vliv archeologicky nezjistitelné příčiny, jako zvláštní okolnosti smrti (např́íklad neobvyklá nemoc, nezvyklé projevy nemoci), rodinné tradice/pověry apod. 
Vybraná pohřebiště poskytují vzorek různých společenských vrstev, které na nich pohřbívaly: od př́slušníků přemyslovské družiny v Lumbeho zahradě přes místního „vladyku“ a jeho rodinu (snad v dobovém smyslu širší rodiny, tedy i se služebníky?) v Klecanech II k pohřebištím Jízdárna, Triangl, Žalov-cihelna i Žalov-Na Panenské a Klecany I v zázemí hradišt', tedy jakémsi „podhradí“, až po venkovská pohřebiště Motol a Brandýsek, na nichž pohřbívali všichni lidé z okolí od místní nobility (která stavěla dřevěné hřbitovní kaple, Sommer 1997; Frolíková-Kaliszová 1999; Vencl 2004) po prosté venkovany. V detailech se pochopitelně jednotlivá pohřebiště liší, na všech se však projevuje rozdíl mezi starším horizontem pohřbívání, datovaným podle honosných šperků velkomoravského rázu nebo skromnějších ozdob podunajského typu, olivovitých korálků a záušnic s očkem od 9. století do první třetiny až poloviny 10. století (Košta-Tomková 2011, 334), a mladším, s výskytem esovitých záušnic a ojedinělé keramiky s kalichovitými okraji. Již H. Zoll-Adamikowa na základě studia pohřebního ritu na rozlehlém území Polska a západních částí Běloruska a Ukrajiny došla $\mathrm{k}$ závěru, že tehdejší křest’anství se v hrobovém rituálu př́liš neprojevovalo, nebot' mělo charakter více rituální než věroučný, více formální a institucionální než skutečně obracející na víru (Zoll-Adamikowa 1971, 125-126), což se ostatně odráží i na našich pohřebištích 9.-10. století. Jak zjistila P. Mašková, církve nezakazovaly ukládání předmětů do hrobů, vymizení milodarů v Čechách v 10. století, jakož i pozdější vymizení osobních šperků, nožů apod. ve 12. století má stejnou příčinu jako vymizení výbavy na pozdně merovejských pohřebištích ve Francii na počátku 8. století, a tou je hlubší proniknutí křest’anské věrouky do myšlení společnosti (Mašková 2009, 78). D. Kalhous zcela odmítá vliv církve na podobu hrobové výbavy, podle něj hrál větší roli sociální status a změny v jeho reprezentaci především u společenských elit $(2019,112-117)$.

Srovnání devíti středočeských pohřebišt' z jádra přemyslovské domény (Sláma 1983, 160-163) ukázalo, že proces christianizace zde probíhal srovnatelným tempem, projevy pohřebního ritu jsou v zásadě shodné, zároveň se však projevují odlišnosti v některých spíše podružných projevech, o jejichž příčinách se můžeme jen dohadovat. Všude se projevuje zhruba stejný průběh pozvolného ústupu od ,,pohanského“ chápání posmrtného života jako pokračování hmotné existence $\mathrm{s}$ nutností vybavit zemřelého potravou během staršího horizontu $\mathrm{k}$ jejímu vymizení $\mathrm{v}$ mladším horizontu. Potravní milodary se $\mathrm{v}$ zásadě přestaly dávat mrtvým $\mathrm{k}$ polovině 10 . století, $\mathrm{v}$ jednotlivých případech se objevily ještě $\mathrm{v}$ průběhu druhé poloviny 10. století. Nešlo zřejmě o žádné pravidlo, nýbrž o individuální záležitost, závislou na archeologicky nepostižitelných okolnostech. Tím se potvrzuje předpoklad, vyslovený v úvodu (Zoll-Adamikowa 1997, 77), že plné prodchnutí života (v našem př́ipadě vlastně smrti) duchem křest’anství trvalo nejméně tři generace: vezmeme-li v potaz dítě narozené v době krátce po křtu Bořivoje a Ludmily, ${ }^{6}$ to ještě žilo se svými rodiči spíše v tradici pohanské, jeho dítě narozené po dvaceti až třiceti letech působení kněží a jejich honosných obřadů (ve zkoumané oblasti je jistě nešlo ignorovat) už žilo dvojvěřím, a u třetí generace asi již mohlo být křest'anské chápání světa $\mathrm{v}$ převaze. Dospělost a hlavně umírání této třetí generace můžeme klást právě do druhé třetiny 10. století, kdy Boleslav I. uctívá svého bratra zemřelého mučednickou smrtí, pozdějšího sv. Václava. Ti, kteří se nestali plně křest’any, o nichž mluví dekreta knížete Břetislava I. a později ještě Břetislava II., asi pohřbívali tajně mimo hřbitovy. Na zkoumaných pohřebištích je nenajdeme, ta jsou křest’anská; nevíme ovšem, jestli byla křest’anská od svého počátku, protože neznámé části pohřebišt' Brandýsek, Triangl (jako část pohřebiště ve strahovské cihelně), obě žalovská pohřebiště i Klecany I byly zničeny před archeologickým výzkumem. Samozřejmě hovoříme o středních Čechách, ve vzdálenějších krajích byl nástup christianizace pozdější a její průběh možná i pomalejší.

Zdá se, že proces christianizace ve středních Čechách se v pohřebním ritu odráží v několika etapách: v první se přechází na pohřbívání nespálených těl (9. století, spíše jeho druhá polovina), ve druhé z hrobů postupně mizí potravinové milodary (během 10. století), ve třetí

6 At' už proběhl kolem roku 883 dle D. Třeštíka (1997, 204), nebo již v letech 878/879 podle L. Havlíka (1992, 219). 
mrtví přestávají být vybavováni předměty vyjadřujícími společenský status rodiny (honosné šperky, ostruhy apod., od druhé poloviny 10 . století) a christianizace je zde dovršena v 11. století. Tzv. obolus mrtvých v našich zemích zřejmě se stavem christianizace nesouvisel.

\section{Prameny}

FROLÍKOVÁ, D., 2013: Nálezová zpráva o záchranném archeologickém výzkumu na lokalitě Praha 6 - Střešovice, novostavba polyfunkčního domu Triangle. Uložena v archivu Archeologického ústavu AV ČR Praha č. j. TX-2013-2514.

\section{Literatura}

BOROŃ, P., 2004: Wiece słowiańskie a decyzja o przyjęciu chrześcijaństwa - możliwości poznawcze. In: Kožiak, R.-Nemeš, J., Pohanstvo a krestanstvo, 95-102. Bratislava.

BRACCINI, T., 2014: Před Draculou. Archeologie upíra. Praha.

BREJCHA, R.-TOMKOVÁ, K., 2020: Výzkum raně středověkých hrobů v Žalově - Na Panenské v sezóně 2013. In: Tomková, K. a kolektiv, Levý Hradec v zrcadle archeologických výzkumů. Pohřebiště. Díl II, 423-435. Praha.

BUKO, A., 2016: Chrześcijanie i poganie. O problemach interpretacji odkryć archeologicznych związanych z początkami chrześcijaństwa na ziemiach polskich, Slavia Antiqua LVII, 13-51.

BRONICKA-RAUHUT, J., 1998: Cmentarzysko wczesnośredniowieczne w Czersku. Warszawa.

ČECH, P.-ČERNÝ, V., 1996: Nové možnosti studia pohřebního ritu na př́ikladu únětických hrobů z Konobrží, okr. Most - Neue Möglichkeiten zum Studium des Bestattungsritus am Beispiel der Aunjetitzer Gräber aus Konobrže, Bez. Most (NW-Böhmen), AR XLVIII, 35-59.

ČERNÝ, V., 1995: Význam tafonomických procesů při studiu pohřebního ritu - Contribution of taphonomy to the study of burial rites, AR XLVII, 301-313.

DOSTÁL, B., 1966: Slovanská pohřebiště ze střední doby hradištní - Slawische Begräbnisstätten der mittleren Burgwallzeit in Mähren. Praha.

- 1992: K pohanství moravských Slovanů, SPFFBU C 39, 7-17.

DYNDA, J., 2017: Slovanské pohanství ve středověkých latinských pramenech. Praha.

EISNER, J., 1952: Devínska Nová Ves. Bratislava.

- 1966: Rukovět' slovanské archeologie. Praha.

FROLÍK, J., 2014: Pohřebiště v Lumbeho zahradě, analýza, chronologie, význam - Cemetery in the Lumbe Garden of the Prague Castle. Analysis, Chronology, Significance. In: Frolík, J. a kol., Pohřebiště v Lumbeho zahradě na Pražském hradě. Díl II. Studie. Castrum Pragense 12/II, 5-116. Praha.

FROLÍK, J., ed., 2015: Pohřebiště u kostela Panny Marie a na II. nádvoří Pražského hradu. Díl I. Katalog. Castrum Pragense 14/I. Praha.

FROLÍK, J., ed., 2017: Pohřebiště u kostela Panny Marie a na II. nádvoří Pražského hradu. Díl II. Analýza. Castrum Pragense 14/II. Praha.

FROLÍK, J., a kolektiv, 2016: Pohřebiště ve vnitřním areálu Pražského hradu. In: Castrum Pragense 15 (Frolík, J.-Válová, K., edd.). Praha.

FROLÍK, J.-SMETÁNKA, Z., 2014: Pohřebiště v Lumbeho zahradě - katalog. In: Frolík, J.-Smetánka, Z., Pohřebiště v Lumbeho zahradě na Pražském hradě. Díl I. Katalog. Castrum Pragense 12/I, 41-212. Praha.

FROLÍKOVÁ-KALISZOVÁ, D., 1999: Dřevěné kostely v Čechách v archeologických pramenech - Bohemian wooden churches in archaeological sources, ASČ 3, 535-545.

- 2000: Pokus o analýzu slovanského pohřebiště v Praze-Motole - Versuch einer Analyse des slawischen Gräberfeld s in Prag-Motol, PA XCI, 201-249.

- 2014: Pohřebiště z 10. století v Praze-Střešovicích - předběžná zpráva - Ein Gräberfeld aus dem 10. Jhdt. in Prag-Stř̌šovice - vorläufiger Bericht, AH 39, 315-329. 
HANULIAK, M., 2000-2001: Pohansko-krestanský synkrestizmus a jeho prejavy na nekropolách z mladšieho úseku včasného stredoveku - Heidnisch-christlicher Synkretismus und seine Äußerungen auf Nekropolen aus dem jüngeren Abschnitt des Frühmittelalters, Studia archaeologica slovaca mediaevalia III-IV, 109-126.

HAVLÍK, L., 1992: Kronika o Velké Moravě. Brno.

HRUBÝ, V., 1955: Staré Město - Velkomoravské pohřebiště Na Valách - Старе Место - великоморавский могилник „На Валах“ - Staré Město - Die Grossmährische Begräbnisstätte „Na Valách“. Praha.

CHORVÁTOVÁ, H., 2004: K interpretáciám a metodologickým riešeniam problematiky prijímania křestanstva vo včasnom stredoveku z pohladu archeológie - Zur Interpretation und zu methodologischen Lösungen des Problems der Christianisierung im frühen Mittelalter in der Archäologie. In: Kožiak, R.Nemeš, J., Pohanstvo a krest’anstvo, 163-170. Bratislava.

- 2004a: Niekol'ko poznámok k otázke „milodarov“ v hroboch včasného stredoveku. In: Zborník na počest' Dariny Bialekovej (Fusek, G., ed.), 143-149. Nitra.

KALHOUS, D., 2019: Graves, Churches, Culture and Texts: The Processes of Christianisation in the Early Middle Ages and their Social and Cultural Context. In: Macháček, J.-Wihoda, M., The Fall of Great Moravia. Who was buried in Grave H 153 at Pohansko near Břeclav?, 110-129. Leiden - Boston.

KLANICA, Z., 1985: Mikulčice-Klášteřisko, PA LXXVI, 474-539.

- 1985a: Náboženství a kult, jejich odraz v archeologických pramenech. In: Poulík, J.-Chropovský, B., a kol., Velká Morava a počátky československé státnosti, 107-139. Praha - Bratislava.

KLÁPŠTĚ, J., 1999: Př́íspěvek k archeologickému poznávání úlohy mince v přemyslovských Čechách - Ein Beitrag zur archäologiskchen Erforschung der Rolle der Münzen in Přemyslidischen Böhmen, AR LI, 774-808.

KOŠTA, J.-TOMKOVÁ, K., 2011: Olivovité korálky v raně středověkých Čechách a jejich postavení ve středovevropském kontextu - Olivenperlen im frühmittelalterlichen Böhmen und ihre Stellung im mitteleuropäischen Kontext, PA CII, 307-354.

KOVÁŘÍK, J., 1991: Slovanské kostrové pohřebiště v Praze 5 - Motole - Das slawische Skelettgräberfeld in Prag 5 - Motol. Archaeologica Pragensia - Claves archaeologicae 1. Praha.

KRUMPHANZLOVÁ, Z., 1961: K otázce vampyrismu na slovanských pohřebištích - Zur Frage des Vampirismus auf den slawischen Gräberfeldern, PA LII, 544-549.

- 1964: Zvláštnosti ritu na slovanských pohřebištích v Čechách - Merkwürdigkeiten im Ritus auf dem slawischen Begräbnisstätte in Böhmen, Vznik a počátky Slovanů 5, 177-215.

- 1971: Počátky křest’anství v Čechách ve světle archeologických pramenů - Die Anfänge des Christentums in Böhmen im Lichte der archäologischen Quellen, PA LXII, 406-430.

- 1972: Die Austattung der Burgwallfriedhöfe in Böhmen und ihre rituelle Bedeutung, Vznik a počátky Slovanů 7, 179-206.

- 1990: Svědectví náboženského synkretismu na pohřebištích doby hradištní v Čechách, AR XLII, 362-368.

- 1997: Kultovní místo na pohřebišti v Lahovicích. In: Kubková, J.-Klápště, J.-Ježek, M.-Meduna, P., Život v archeologii středověku, 394-401. Praha.

KRUMPHANZLOVÁ, Z., a kol., 2013: Raně středověké pohřebiště v Praze-Lahovicích. Praha.

KRUTINA, I.-PROFANTOVÁ, N., 2001: Pohřebiště v areálu hradiště v Klecanech, okr. Praha-východ. Zprávy České archeologické společnosti - Supplément 45 - Archeologické výzkumy v Čechách 2000, 25. Praha.

KYSELÝ, R., 2010: Pohřebiště Klecany I. Zviŕrecí kosti. In: Profantová, N. a kolektiv, Klecany - raně středověká pohřebiště II, 25-26. Praha.

KYTLICOVÁ, O., 1968: Slovanské pohřebiště v Brandýsku - Das slawische Gräberfeld von Brandýsek, PA LIX, 193-246.

MAREŠOVÁ, K., 1970: Projevy totemismu u Slovanů - Nach Klänge von Totemismus bei den Altslawen, SbNM A XXIV, 123-127.

- 1983: Uherské Hradiště-Sady. Staroslovanské pohřebiště na Horních Kotvicích - Altslawische Bergräbnisstätte in Uherské Hradišše-Sady - Древнеславянское погребение в городе Угерске Градище-Сады. Brno - Uherské Hradiště. 
MAŘÍK, J., 2001: Ecclesia lignea, memoria nebo něco úplně jiného? In: Doležalová, I.-Meduna, P., Co můj kostel dnes má, nemůže mi kníže odníti, 41-45. Praha.

MAŠKOVÁ, P., 2009: K obrazu středověkého pohřebiště - církevní normy a výpověd' archeologických pramenů. In: Duroszewski, M., Kościól w monarchii Przemyślidów i Piastów, 73-85. Poznań.

MAZUCH, M.-HLADÍK, M.-SKOPAL, R., 2017: Úpravy hrobových jam a dřevěné konstrukce v hrobech na pohřebištích Velké Moravy (sociální, duchovní a chronologický fenomén) - Burial Pit Arrangements and Wooden Structures in Graves at Great Moravian Necropolises (Social, Spiritual and Chronological Phenomenon). Spisy AÚ AV ČR Brno 56. Brno.

NIEDERLE, L., 1911: Slovanské starožitnosti. Díl I. Život starých Slovanů. Praha.

- 1953: Rukovět' slovanských starožitností. Praha.

PROFANTOVÁ, N., 2010: Pohřebiště Klecany II. In: Profantová, N. a kolektiv, Klecany - raně středověká pohřebiště II - Die frühmittelalterliche Gräberfelder in Klecany, 73-93. Praha.

- 2011: Pohřebiště Klecany I. In: Profantová, N. a kolektiv, Klecany - raně středověká pohřebiště I, 15-128. Praha.

- 2011a: Pohřebiště Klecany II. In: Profantová, N. a kolektiv, Klecany - raně středověká pohřebiště I, 147-188. Praha.

- 2011b: Poznatky o hradišti. In: Profantová, N. a kolektiv, Klecany - raně středověká pohřebiště I, 189-210. Praha.

PROFANTOVÁ, N.-KRUTINA, I., 2011: Pohřebiště Klecany II. In: Profantová, N. a kolektiv, Klecany - raně středověká pohřebiště I, 139-146. Praha.

PROKEŠ, L., 2007: Posmrtné změny a jejich význam při interpretaci pohřebního ritu (Ke vztahu mezi archeologií a forenzními vědami) - Post-mortem changes and their meaning in the interpretation of the burial rite (Relation between archaeology and forensic science). Archaeologia mediaevalis Moravica et Silesiana - Supplementum 1. Brno.

SKUTIL, J., 1939: Drobné příspěvky k poznání staroslovanské kultury, Sborník velehradský - NŘ 10, $26-36$.

SLÁMA, J., 1983: Př́nos archeologie k poznání počátků přemyslovského státu - Beitrag der Archäologie zur Kenntnis der Anfänge des Přemysliden-Staates, SbNM A XXXVII, 159-169.

SLIVKA, M., 2000-2001: Doterajšie poznatky z dejín a kultúry krest’anstva na Slovensku (4.-15. stor.), Studia archaeologica slovaca mediaevalia III-IV, 17-50.

- 2004: K náboženskému synkretizmu v strednej Európe - On Religious Syncretism in the Central Europe. In: Kožiak, R.-Nemeš, J., Pohanstvo a krest’anstvo, 147-162. Bratislava.

SMETÁNKA, Z., 1988: Stopa magického jednání na pohřebišti za Jízdárnou Pražského hradu - A trace of magical procedure of the Early Mediaeval cemetery behind the Riding School of Prague Castle, Sborník Kruhu př́tel Muzea hl. m. Prahy 1, 94-107.

- 2014: Vejce a skořápky vajec - Eggs and Eggshells. In: Frolík, J. a kol., Pohřebiště v Lumbeho zahradě na Pražském hradě. Díl II. Studie. Castrum Pragense 12/II, 117-128. Praha.

SOMMER, P., 1996: Christianizace střední Evropy a archeologické prameny - Christianisierung Mitteleuropas und die archäologische Quellen, Slavia Antiqua XXXVII, 137-145.

- 1997: Raně středověká ecclesia lignea a archeologie - Frühmittelalterliche ecclesia lignea und Archäologie. In: Z pravěku do středověku. Sborník k 70. narozeninám Vladimíra Nekudy (Michna, P.-Nekuda, R.-Unger, J., edd.), 276-279. Brno.

ŠIKULOVÁ, V., 1959: Moravská pohřebiště z mladší doby hradištní - Mährische Gräberfelder der jüngeren Burgwallperiode, Pravěk východní Moravy I/1958, 88-162.

ŠTEFAN, I., 2007: Změna pohřebního ritu v raném středověku jako archeologický a kulturně-antropologický problém - The change in burial rites in the Early Middle Ages as an issue for archaeology and cultural anthropology, AR LIV, 805-836.

ŠUSTA, J., 2002: Dvě knihy českých dějin. Kus středověké historie našeho kraje. Kniha druhá: Počátky lucemburské. Praha.

TÉRA, M., 2014: Slovanské archaické náboženství. In: Velká Morava a počátky křest’anství (Kouřil, P., ed.), 40-45. Brno.

TOMKOVÁ, K., 2001: Levý Hradec v zrcadle archeologických výzkumů. Díl I. Castrum Pragense 4. Praha. 
- 2005: Pohřební ritus na Pražském hradě a jeho předpolích ve středověku a novověku - charakteristika a vývoj - Der Bestattungsritus auf der Prager Burg und auf ihren Vorfeldern im Mittelalter und der Neuzeit - Beschreibung und Entwicklung. In: Pohřbívání na Pražském hradě a jeho předpolích. Díl I.1. Castrum Pragense 7/I.1 (Tomková, K., ed.), 159-196; Castrum Pragense 7/I.2 (Tomková, K., ed.), 266-268. Praha.

- 2005a: Hmotná kultura raně středověkých pohřebišt' Pražského hradu a jeho předpolí - Das Grabinventar auf den frühmittelalterlichen Gräberfeldern der Prager Burg und ihrer Vorfeldern. In: Pohřbívání na Pražském hradě a jeho předpolích. Díl I.1. Castrum Pragense 7/I.1 (Tomková, K., ed.), 217-304; Castrum Pragense 7/I.2 (Tomková, K., ed.), 270. Praha.

- 2005b: Pohřebiště Jízdárna (Úvod) - Das Gräberfeld bei der Reitschule (Einleitung). In: Pohřbívání na Pražském hradě a jeho předpolích. Díl I/1. Castrum Pragense 7/I.1 (Tomková, K., ed.), 387-402; Castrum Pragense 7/I.2 (Tomková, K., ed.), 275-276. Praha.

- 2006: Raně středověká pohřebiště na předpolí Pražského hradu. In: Pohřbívání na Pražském hradě a jeho předpolích. Díl I/2. Castrum Pragense 7/I.2 (Tomková, K., ed.), 5-128. Praha.

- 2012: Pohřebiště na Levém Hradci a jeho předpolí. Katalog. - Die Gräberfeld in Levý Hradec und auf seinen Vorfeldern. Katalog. In: Tomková, K. a kolektiv, Levý Hradec v zrcadle archeologických výzkumů. Pohřebiště. Díl I, 7-172. Praha.

- 2020: I. část - Pohřebiště. In: Tomková, K. a kolektiv, Levý Hradec v zrcadle archeologických výzkumů. Pohřebiště - Levý Hradec in the mirror of archaeological excavations. Cemeteries. Díl II, 7-172. Praha.

- 2020a: Několik poznámek k tématu archeologie vejce - Several notes on "egg archaeology". In: Tomková, K. a kolektiv, Levý Hradec v zrcadle archeologických výzkumů. Pohřebiště. Díl II, 305-314, 512. Praha.

TŘEŠTíK, D., 1997: Počátky Přemyslovců, vstup Čechů do dějin. Praha.

- 2003: Mýty kmene Čechů. Praha.

TURČAN, V., 2004: Slovanský kultový objekt v Moste při Bratislave. In: Krekovič, E., Kult a mágia v materiálnej kultúre, 59-61. Bratislava.

- 2012: Pôvodné slovanské náboženstvo a kristianizácia stredodunajských Slovanov. In: Panis, B.Ruttkay, M.-Turčan, V., Bratia, ktorí menili svet - Konštantín a Metod, 71-78. Bratislava.

UNGER, J., 2007: Pohřební ritus a proměny chápání cesty dítěte na druhý svět v prvním a druhém tisíciletí - Bestattungsritus und Veränderungen in der Auffassung des Weges des Kindes ins Jenseits im 1. und 2. Jahrtausend, ŠZ 42, 211-220.

VENCL, S., 2004: Dřevěná sakrální architektura a archeologie. In: Kazdová, E.-Měřínský, Z.-Šabatová, K., K poctě Vladimíru Podborskému. Přátelé a žáci k sedmdesátým narozeninám, 517-524. Brno.

ZOLL-ADAMIKOWA, H., 1971: Wczesnośredniowieczne cmentarzyska szkieletowe Małopolski. Wrocław.

- 1997: Stan badań nad obrzędowością pogrzebową Słowian - Zum Forschungsstand des Bestattungsbrauchtums der Slawen, Slavia Antiqua XXXVIII, 65-80.

ŽEMLIČKA, J., 2014: Christianizace a etatizační proces ve střední Evropě - In: Kouřil, P. a kol., Cyrilometodějská misie a Evropa - 1150 let od př́íchodu soluňských bratř́i na Velkou Moravu, 22-26. Brno.

\section{Zusammenfassung}

Die Spiegelung des Christianisierungsprozesses auf ausgewählten Gräberfeldern des Přemyslidendominiums

$\mathrm{Zu}$ den allgemein anerkannten Erscheinungsformen der Christianisierung auf flachen Skelettgräberfeldern zählen laut Z. Krumphanzlová ein Rückgang an Grabbeigaben, die Nord-Ost-Orientierung der Verstorbenen, die Verwendung von Stein bei der Herrichtung des Grabs und Änderungen in der inneren Anordnung von Friedhöfen (Krumphanzlová 1971, 420-423). Die wachsende Zahl von Gräbern für Kleinkinder auf Friedhöfen wird von J. Unger (2007, 214-215) als stärker werdener Einfluss des Christentums angesehen. Wenn wir Erscheinungsformen des Christentums untersuchen wollen, müssen wir von den Zentren aus vorgehen, von denen die 
Christianisierung ausging, d.h. von den Siedlungsburgstätten der Přemyslidenfürsten. Untersucht werden zwei Gräberfelder in Prag im Areal der Prager Burg und das Gräberfeld Triangel in ihrem wirtschaftlichen Hinterland, zwei Gräberfelder im Areal Žalov auf der Vorburg der Burgstätte Levý Hradec, zwei Gräberfelder im nahegelegenen Klecany und die zwei ländlichen Gräberfelder Prag-Motol und Brandýsek (Abb. 1). Die Grabbeigaben müssen unterschieden werden in Sachen, die Bestandteil der Kleidung waren, Schmuck, sowie Sachen, die üblicherweise am Gürtel getragen wurden (Messer, Utensiliern zum Feuerschlagen) und Liebesgaben (Krumphanzlová 1972, 197). Liebesgaben im eigentlichen Sinne waren reale oder symbolische Lebensmittel (Fleisch, bzw. Tierknochen, Eier) einschließlich ihrer Verpackung (Keramiktöpfe, Schalen, Flaschen, Holzeimer). Ein Sonderfall sind Waffen, die auf den hier erörterten Gräberfeldern nur durch Äxte und Pfeile vertreten sind.

Auf dem reichen Gräberfeld im Prager Lumbe-Garten wurden Liebesgaben nur in einer geringen Anzahl von Fällen in die Gräber gegeben, jedoch über das gesamte 10. Jahrhundert hinweg, ohne einen statistisch deutlichen Unterschied zwischen Kindern und Erwachsenen (Frolík 2014, 77). Das gleiche gilt für die Verwendung von Stein. Das benachbarte ärmere Gräberfeld Jízdárna korrespondiert voll und ganz mit den Feststellungen vom Lumbe-Garten (Tomková 2005). Auf dem Gräberfeld Triangel wurden Liebesgaben in Form von Eiern oder Lebensmitteln in Gefäßen nur in den Kindergräben entdeckt (Frolíková-Kaliszová 2014). Auf den Gräberfeldern Levý Hradec-Žalov zeigt sich im Hinblick auf den Einfluss des aufkommenden Christentums eine zeitliche Abfolge - das ältere Gräberfeld Žalov - Na Panenské mit unregelmäßiger Gräberverteilung und das jüngere Žalov - Ziegelei (cihelna) mit mehr oder weniger geordneter Anordnung (Tomková 2020, 287). Auf dem Gräberfeld Klecany I in der Vorburg beobachten wir Liebesgaben ungefähr bis Mitte des 10. Jahrhunderts, auf dem Gräberfeld Klecany II Na Hradisku (auf dem Burgwall) haben die Gräber ab Anfang des 10. Jahrhunderts keine Liebesgaben (Profantová 2011, 126; 2011a, 160). Brandýsek weist einen Übergang von einzeln angelegten Gräbern mit leicht schwankender Orientierung und beigegebenen Gefäßen, Eimern oder Pfeilen hin zu Gräbern mit gleicher Orientierung auf, in denen S-förmige Schläfenringe vorkommen (Kytlicová 1968). Auf dem Gräberfeld Motol ist ein Unterschied zwischen dem älteren Horizont mit Liebesgaben und ihrem sukzessiven Rückgang und umgekehrt einer Zunahme von mit Steinen hergerichteten Gräbern zu erkennen (Kováŕík 1991). Auf dem ländlichen Gräberfeld Motol wurde in seiner jüngeren Phase wahrscheinlich eine kleine Holzkirche oder eher nur eine Friedhofskapelle errichtet (Abb. 2, 3).

Auf allen ausgewählten Gräberfeldern ist ein Unterschied zwischen dem älteren Bestattungshorizont, der anhand von Luxusschmuck großmährischen Charakters oder bescheideneren Schmuckstücken eines aus dem Donauraum stammenden Typs und olivenförmigen Perlen und Schläfenringen mit Öse in die Zeit zwischen dem 9. Jahrhundert und dem ersten Drittel bis Mitte des 10. Jahrhunderts datiert wird, und dem jüngeren Horizont erkennbar, in dem S-förmige Schläfenringe und nur vereinzelt Keramik mit kelchförmigen Rändern vorkommen. In den Details unterscheiden sich die einzelnen Gräberfelder, es zeigt sich jedoch überall ungefähr der gleiche Verlauf eines Rückzugs vom heidnischen Verständnis vom Leben nach dem Tod mit der Notwendigkeit, im älteren Horizont den Verstorbenen mit Lebensmitteln auszustatten hin zum Verschwinden der Liebesgaben im jüngeren Horizont. Die Verwendung von Steinen bei der Herrichtung der Grabgruben kann am Beispiel der Bestattungen der Herrscherschicht in Steingruften und unter Grabmalen bei Kirchen erklärt werden. Eine kritische Auswertung zeigt die Problemhaftigkeit vieler Gräber auf, bei denen man früher „Maßnahmen gegen Vampire“ erkannt hatte.

Ein Vergleich von neun mittelböhmischen Gräberfeldern aus dem Kerngebiet des přemyslidischen Dominiums (Sláma 1983, 160-163) hat gezeigt, dass der Chrisianisierungsprozess dort in einem ähnlichen Tempo verlief, die Erscheinungsformen des Bestattungsritus sind im Grunde genommen gleich, gleichzeitig tauchen jedoch Unterschiede in einigen eher nebensächlichen Erscheinungsformen auf, über deren Ursachen wir nur spekulieren können. Der Christianisierungsprozess in Mittelböhmen spiegelt sich in mehreren Etappen wider: in der ersten geht man 
dazu über, unverbrannte Körper zu bestatten (9. Jhdt., eher dessen zweite Hälfte), in der zweiten verschwinden Lebensmittelbeigaben nach und nach aus den Gräbern (im 10. Jhdt.), und in der dritten hört man damit auf, die Toten mit Gegenständen auszustatten, die den gesellschaftlichen Status der Familie zum Ausdruck bringen (Luxusschmuck, Sporen u.ä., ab der zweiten Hälfte des 10. Jhdts.). Die Christianisierung erreicht dort im 11. Jahrhundert ihre Vollendung. Dadurch wird die Annahme bestätigt, dass die Durchdringung des Lebens (in unserem Falle eigentlich des Todes) mit dem Geist des Christentums mindestens drei Generationen gedauert hat (Zoll-Adamikowa 1997, 77); in Mittelböhmen heißt das ab der Taufe von Fürst Bořivoj und Fürstin Ludmilla (spätestens Anfang der achtziger Jahre des 9. Jhdts.) bis zur Herrschaftszeit ihres jüngsten Enkels Boleslav I. (935-967/972).

PhDr. Drahomíra Frolíková-Kaliszová, Ph.D., Archeologický ústav AV ČR, Praha, v. v. i., Letenská 4, 11801 Praha 1, Česká republika,frolikova@arup.cas.cz 
